\title{
SPLUNC1: A Novel Marker of Cystic Fibrosis Exacerbations
}

\author{
Sara Khanal ${ }^{1}$, Megan Webster ${ }^{2}$, Naiqian Niu ${ }^{1}$, Myra Nunez $^{4}$, Geoffrey Chupp ${ }^{1}$, Martin D. \\ Slade ${ }^{1}$, Lauren Cohn ${ }^{1}$, Maor Sauler ${ }^{1}$, Jose L. Gomez ${ }^{1}$, Robert Tarran ${ }^{2}$, Lokesh Sharma ${ }^{1}$, \\ Charles S. Dela Cruz ${ }^{1}$, Marie Egan ${ }^{3}$, Theresa Laguna ${ }^{4}$, Clemente J. Britto ${ }^{1}$ \\ ${ }^{1}$ Section of Pulmonary, Critical Care and Sleep Medicine \\ Yale University School of Medicine \\ New Haven, Connecticut 06520 \\ ${ }^{2}$ Department of Cell Biology \& Physiology \\ University of North Carolina \\ Chapel Hill, North Carolina 27599 \\ ${ }^{3}$ Division of Pediatric Pulmonology, Allergy, Immunology, and Sleep Medicine \\ Yale University School of Medicine \\ New Haven, Connecticut 06510 \\ ${ }^{4}$ Division of Pediatric Respiratory Medicine \\ University of Minnesota \\ Minneapolis, Minnesota 55454
}

Corresponding Author: Clemente Britto MD

Mailing address:

Clemente Britto MD

Yale University School of Medicine

Section of Pulmonary, Critical Care and Sleep Medicine

333 Cedar Street, PO Box 208057

New Haven, CT 06520-8057

Phone: 203-785-3627

FAX: 203-785-6094

Clemente.britto@yale.edu

Running Title: SPLUNC1: A Novel Marker of CF Exacerbations

This work was supported by NIH R01-HL081160 and R21-AI083475 (LC), NIH T32HL007778, NIH/NHLBI K01-HL125514-01, and Cystic Fibrosis Foundation's Fifth Year Clinical Fellowship (CB), American Thoracic Society Foundation Unrestricted Research Award (CB), CF Foundation (RT); UK CF Trust (RT). 
medRxiv preprint doi: https://doi.org/10.1101/2020.05.15.20100669; this version posted May 19, 2020. The copyright holder for this preprint (which was not certified by peer review) is the author/funder, who has granted medRxiv a license to display the preprint in perpetuity.

It is made available under a CC-BY-NC-ND 4.0 International license .

\section{ABSTRACT}

Acute pulmonary Exacerbations (AE) are episodes of clinical worsening in cystic fibrosis (CF), often precipitated by infection. Timely detection is critical to minimize the morbidity and lung function decline associated with acute inflammation during AE. We previously demonstrated that the airway protein Short Palate Lung Nasal epithelium Clone 1 (SPLUNC1) is regulated by inflammatory signals. Here, we investigated the use of SPLUNC1 fluctuations to diagnose and predict AE in CF.

We enrolled adult CF subjects from two independent cohorts to measure AE markers of inflammation in sputum and recorded clinical outcomes for a 1-year follow-up period.

SPLUNC1 levels were high in healthy control sputum $(n=9,10.7 \mu \mathrm{g} / \mathrm{mL})$, and significantly decreased in $\mathrm{CF}$ subjects without $\mathrm{AE}(n=30,5.7 \mu \mathrm{g} / \mathrm{mL}, p=0.016)$. SPLUNC1 levels were $71.9 \%$ lower during $\mathrm{AE}(n=14,1.6 \mu \mathrm{g} / \mathrm{mL}, p=0.0034)$ regardless of age, sex, CF-causing mutation, or microbiology findings. Cytokines Il-1 $\beta$ and TNF $\alpha$ were also increased in AE, whereas lung function did not consistently decrease. Stable CF subjects with lower SPLUNC1 levels were much more likely to have an AE at 60 days (Hazard Ratio: 11.49, Standard Error: 0.83, $p=0.0033)$. Low-SPLUNC1 stable subjects remained at higher AE risk even one year after sputum collection (Hazard Ratio: 3.21, Standard Error: 0.47, $p=0.0125$ ). SPLUNC1 was transcriptionally downregulated by inflammatory cytokines and degraded by proteases increased in sputum during AE.

Our findings suggest that low sputum SPLUNC1 levels could detect subjects at increased risk of $\mathrm{AE}$ in order to guide early therapeutic interventions in $\mathrm{CF}$. 


\section{TAKE-HOME MESSAGE}

Sputum concentrations of the secreted airway protein SPLUNC1 decrease during CF exacerbations. Lower SPLUNC1 levels in stable subjects portend a significantly increased risk of exacerbation and could inform therapeutic interventions.

\section{PLAIN LANGUAGE SUMMARY}

SPLUNC1 is an abundant host defense protein found in the respiratory tract that decreases with inflammation. Individuals with cystic fibrosis experiencing clinical worsening (exacerbation) have much lower levels of SPLUNC1 in their sputum. In stable cystic fibrosis patients, lower levels of SPLUNC1 may predict an upcoming respiratory illness. Therefore, SPLUNC1 may serve as a tool for early diagnosis and treatment of cystic fibrosis exacerbations. 
medRxiv preprint doi: https://doi.org/10.1101/2020.05.15.20100669; this version posted May 19, 2020. The copyright holder for this preprint

\section{BACKGROUND}

Cystic fibrosis (CF) is one of the most common life-shortening genetic diseases in the United States[1-3]. The primary cause of mortality in CF is lung disease, characterized by persistent airway and lung inflammation leading to lung function decline $[4,5]$. CF exacerbations (AE) are acute declines in a CF subject's clinical condition, associated with increased morbidity, healthcare costs, and worsening quality of life [5-9]. AE are associated with increased lung inflammation, manifested as rising concentrations of airway cytokines and proteases that contribute to further lung injury in $\mathrm{CF}[7,10]$.

The early diagnosis and treatment of $\mathrm{AE}$ is important to minimize morbidity and disease progression in $\mathrm{CF}$. In order to support clinical decision-making, markers of acute inflammation or lung function decline can be used. Decreases in the Forced Expiratory Volume in the first second $\left(\mathrm{FEV}_{1}\right)$, a measure of pulmonary function, can reflect lung function decline during AE. However, these changes often occur as a late consequence of lung inflammation, limiting its clinical usefulness for early AE detection [11]. Inflammatory cytokines (e.g. IL-6, IL-8, TNF $\alpha$ ) have also been linked to AE, but delayed upregulation and limited data on their ability to predict AE limit their clinical usefulness. The development of early non-invasive markers to predict clinical deterioration before $\mathrm{FEV}_{1}$ or cytokine fluctuations would be a significant advancement to detect $\mathrm{AE}$ and limit its impact on long-term health in CF[12-14].

In our previous studies, we demonstrated that airway concentrations of host defense protein Short Palate Lung Nasal epithelium Clone 1 (SPLUNC1, also known as BPI-fold containing family member A1, BPIFA1), are closely regulated by microbial and inflammatory signals, as well as proteases [15-18]. SPLUNC1 is abundant in human 
respiratory secretions and downregulated within hours by inflammation, suggesting that it could be an early marker of airway irritant exposures or acquisition of pathogens likely to induce clinical deterioration[19].

Here, we hypothesized that SPLUNC1 concentrations in sputum would decrease sharply during $\mathrm{AE}$, and that lower levels of SPLUNC1 would be associated with adverse CF clinical outcomes. We measured SPLUNC1 fluctuations during AE and performed experiments to define the mechanisms that underlie SPLUNC1 regulation. Our findings provide evidence for the use of SPLUNC1 as a marker and predictor of AE that can inform clinical decision-making in CF care. 


\section{MATERIALS AND METHODS}

\section{Detailed methods in Supplemental Methods Section}

\section{Study Design}

This was a two-center, prospective, longitudinal study of CF subjects during periods of clinical stability and AE. All patients received standard-of-care therapy, and cystic fibrosis transmembrane conductance regulator (CFTR) modulators when they became available. The primary objective of this study was to define an association between $\mathrm{AE}$ and sputum levels of SPLUNC1. Each subject provided a sputum sample and underwent spirometry within 24 hours of sample collection. Subjects were followed at quarterly outpatient clinic visits, or sooner when indicated, for up to one year (Supplemental figure 1). Clinical information, expectorated sputum, and pulmonary function testing data were collected at each clinic visit.

\section{Definition of CF Exacerbation}

$\mathrm{CF} \mathrm{AE}$ were defined as the emergence of 4 of 12 signs or respiratory symptoms, prompting changes in therapy and initiation of antibiotics (modified from Fuchs' criteria [21]). These criteria included: change in sinus congestion, sputum, or hemoptysis; increased cough, dyspnea, malaise, fatigue or lethargy; fever; hyporexia or weight loss; change in chest physical exam; or $\mathrm{FEV}_{1}$ decrease $>10 \%$ from a previous value [21]. Individuals not meeting AE criteria were characterized as "CF Stable".

\section{Cohort Characteristics}


medRxiv preprint doi: https://doi.org/10.1101/2020.05.15.20100669; this version posted May 19, 2020. The copyright holder for this preprint

Discovery cohort: 44 adults with confirmed CF diagnosis from the Yale Adult CF Program were recruited during a) scheduled routine visits, b) unscheduled visits in which they reported $\mathrm{AE}$ symptoms, and c) on the first day of admission to the hospital for $\mathrm{AE}$ treatment. The recruitment period extended from 2014-2016. We organized study subjects in two groups: 1) Stable CF subjects (CF Stable): No new respiratory symptoms, presenting to clinic for scheduled follow up and, 2) AE subjects (AE): Diagnosed with AE (Table 1). We also recruited 10 healthy controls (HC) to undergo sputum induction according to published protocols [22]. The study was approved by the Yale University Institutional Review Board and informed consent was obtained from each subject.

Validation cohort: 35 adult and pediatric subjects with a confirmed CF diagnosis, previously enrolled in a sputum study of $\mathrm{AE}$ at the University of Minnesota (UMN) were included. This was a prospective study of patients hospitalized for AE treatment [12]. All patients received standard-of-care therapy and each subject provided sputum samples and performed pulmonary function tests within 72 hours of intravenous antibiotic initiation (Table 2)[23].

\section{Sputum Collection and Processing}

CF subjects expectorated sputum spontaneously for airway cultures and provided an additional sample for our study. Induced sputum samples were obtained from $\mathrm{HC}$ by sputum induction as previously reported[22, 24]. Sputum was processed as previously reported [20].

\section{SPLUNC1 and Cytokine ELISA, Western Blot}


medRxiv preprint doi: https://doi.org/10.1101/2020.05.15.20100669; this version posted May 19, 2020. The copyright holder for this preprint

We developed and optimized a sputum SPLUNC1 ELISA for this study, which is detailed in the supplemental methods. Human SPLUNC1 recombinant protein was used as a reference (cat\# H00051297-P01, Abnova, Taipei, Taiwan). Detection antibody: polyclonal mouse anti-human SPLUNC1 IgG (cat\# SAB1401687, MilliporeSigma, Burlington, MA). Secondary antibody: HRP-conjugated anti-mouse IgG (cat\# G21040, Invitrogen, Carlsbad, CA). Chromogenic tetramethylbenzidine substrate was applied (KPL, Gaithersburg, MD) and reactions were measured at optical densities of 450 and $550 \mathrm{~nm}$. The assay limits of detection were $1-20,000 \mathrm{ng} / \mathrm{mL}$. Mean intra-assay variability: 5.18\% (STDEV 1.28\%), Inter-assay variability: 18.44\% (STDEV 12.95\%). For cytokine detection we used multiplexed cytokine ELISA assays (Mesoscale Diagnostics. Rockville, MD, coefficient of variability $<25 \%$ ). Western blots were performed as previously reported, using human neutrophil elastase (NE, hELA2) mouse monoclonal anti-hELA2 IgG (cat\# MAB-91671-100, R\&D systems) and mouse polyclonal anti-human SPLUNC1 IgG [17]. Densitometry was determined using ImageJ software.

\section{Sputum NE Activity and SPLUNC1 Degradation Assays}

NE activity was determined using the 7-amino-4-methylcoumarin (MCA) assay (\#MAA-3133; Peptides International, Louisville, KY), as previously described [17]. For degradation assays, recombinant human SPLUNC1 was incubated with recombinant human NE (rhNE, R\&D systems cat\#9167-SE-020) or Pseudomonas aeruginosa elastase (LasB, a gift from Dr. Karen Agaronyan, Yale) at a concentration of $5 \mu \mathrm{g} / \mathrm{ml}$ for 24 hours. SPLUNC1 was measured by ELISA.

\section{Regulation of Epithelial Cytokine Expression}


medRxiv preprint doi: https://doi.org/10.1101/2020.05.15.20100669; this version posted May 19, 2020. The copyright holder for this preprint

Mouse tracheal epithelial cells (mTECs) were isolated from C57BL/6 mice and cultured at air-liquid interface (ALI) as previously described [15]. mTECs were treated with recombinant murine IL-1 $\beta$ (cat\# 211-11b, Peprotech, Rocky Hill, NJ) or TNF- $\alpha$ (cat\# 315-01A, Peprotech), at $10 \mathrm{ng} / \mathrm{mL}$ for 24 hours. NCI-H292 human airway epithelial cells (shown to abundantly express SPLUNC1 and to be robustly regulated by inflammatory cytokines [15]), were treated with recombinant human IL-1 $\beta$ (cat\# PHC0811, Gibco, Gaithersburg, MD) or TNF- $\alpha$ (cat\# 210-TA-005, R\&D, Minneapolis, MN) at $10 \mathrm{ng} / \mathrm{ml}$. Cellular mRNA was extracted for qPCR, and SPLUNC1 qPCR assays were performed to quantify SPLUNC1 transcriptional regulation as described[15].

\section{Statistical Analysis}

Descriptive statistics were calculated for the entire subject population. Pearson correlations, or Spearman correlations for variables that were not normally distributed, were calculated between SPLUNC1 and clinical parameters. In order to select the optimal threshold of SPLUNC1 and cytokine concentrations that identify a subject group at higher $\mathrm{AE}$ risk, we calculated receiver-operating curves (ROC) based on the distribution of SPLUNC1, IL-1 $\beta$, TNF $\alpha$, G-CSF, IL-6, and IL-8 levels in the discovery cohort (Supplemental Figure 3). Using this threshold, we applied statistical modeling (MantelHaenszel estimator) to predict AE-free intervals. AE-free interval was defined as the time in days from sputum sampling in a stable subject to the time of the first AE after that visit. Cox proportional hazards model was conducted with clinical parameters as covariates. A backward elimination strategy with a significance level to stay of $95 \%(a=0.05)$ was 
medRxiv preprint doi: https://doi.org/10.1101/2020.05.15.20100669; this version posted May 19, 2020. The copyright holder for this preprint (which was not certified by peer review) is the author/funder, who has granted medRxiv a license to display the preprint in perpetuity. It is made available under a CC-BY-NC-ND 4.0 International license .

employed to achieve a parsimonious model. All statistical analyses were conducted using SAS 9.4 with a level of significance of $95 \%(\alpha=0.05)$. 


\section{RESULTS}

\section{SPLUNC1 is Decreased in the Sputum of Stable CF Subjects}

SPLUNC1 levels ranged from 4.41 to $22.24 \mu \mathrm{g} / \mathrm{mL}$ in the sputum of healthy controls (HC). In stable CF subjects (CF Stable), SPLUNC1 was significantly decreased, whereas total sputum protein was increased (Figure 1A, 1B). To further characterize the inflammatory profile of stable CF subjects, we measured sputum concentrations of inflammatory cytokines previously reported to be increased in CF. Of these, IFN $\alpha$, IFN $\gamma$, IL1 $\beta$, IL-8, IL-13, and TNF $\alpha$ were significantly increased in CF (Figure $1 C$ ). When separated according to CF-causing mutation genotype, there were no differences in SPLUNC1 levels of stable subjects with homozygous, heterozygous, or no F508del genotype (Supplemental Figure 2). Furthermore, SPLUNC1 was decreased in CF regardless of the presence of CF-related complications, microbiology findings, and CFTR modulator therapies (Tables 1 and 2). These findings indicate that SPLUNC1 is abundant in sputum and decreased in stable CF subjects.

\section{SPLUNC1 is Decreased During CF Exacerbations}

$\mathrm{AE}$ are frequently caused by new airway infection and increased airway inflammation. Therefore, we hypothesized that SPLUNC1 levels would decrease during AE. To test this, we measured SPLUNC1 levels in sputum from stable CF and AE subjects. SPLUNC1 decreased sharply during AE in the discovery cohort (Yale University, 71.9\% decrease) and in the validation cohort (UMN, 38.6\% decrease) (Figure 2). In contrast, 
medRxiv preprint doi: https://doi.org/10.1101/2020.05.15.20100669; this version posted May 19, 2020. The copyright holder for this preprint

$\mathrm{FEV}_{1}$, a marker of lung function widely used to diagnose $\mathrm{AE}$, did not decrease in the Yale AE group, but was significantly decreased in the UMN AE group.

We hypothesized that individuals receiving intravenous antibiotics (IV) for $\mathrm{AE}$ would be more severely ill and have more airway inflammation than those treated with oral antibiotics, thus IV-treated subjects would have larger drops in SPLUNC1. To test this, we measured SPLUNC1 in sputum of AE subjects being treated with oral antibiotics as outpatient (AEOP) or IV antibiotics as inpatient (AEIP) in the UMN cohort. In both treatment groups, SPLUNC1 was lower than in stable CF subjects, however there was no difference between AEOP and AEIV levels of SPLUNC1 (Supplemental Figure 4). This indicates that acute drops in sputum SPLUNC1 occur consistently during AE regardless of AE severity.

Next, we sought to define SPLUNC1 fluctuations during AE within the same individuals, relative to their stable-state reference value (subject-specific fluctuations). We compared SPLUNC1 and $\mathrm{FEV}_{1}(\%)$ in paired samples from the same subjects, collected during stable and AE periods. SPLUNC1 decreased during AE in both the Yale and UMN cohorts (Figure 3). In contrast, $\mathrm{FEV}_{1}$ only decreased during $\mathrm{AE}$ in the UMN cohort. These findings suggest that SPLUNC1 is consistently decreased during AE, while FEV1 decreases during $\mathrm{AE}$ vary across cohorts.

\section{Low SPLUNC1 Levels in Sputum Predict AE-Free Time in Stable CF Subjects}

To determine if SPLUNC1 is a predictor of AE-free time, the number of days from sputum collection in stable patients to the next time they were diagnosed with $\mathrm{AE}$, we performed a Mantel-Haenszel survival estimator analysis for AE-free time after separating the groups into high- and low-SPLUNC1 (Detailed methods, Supplemental figures 3, 5). In 
medRxiv preprint doi: https://doi.org/10.1101/2020.05.15.20100669; this version posted May 19, 2020. The copyright holder for this preprint

stable CF subjects, the SPLUNC1-low group had a median AE-free time of 43.5 days compared to 150 days in the SPLUNC1-high group. This indicates that high SPLUNC1 levels are associated with more AE-free days.

Next, we performed Cox-proportional Hazards modeling to assess the likelihood of AE when adjusting for demographics, CF-related comorbidities, microbiology, and lung function. SPLUNC1 remained a strong predictor of AE-free time regardless of F508del mutation status, microbiology, or severity of $\mathrm{FEV}_{1}$ impairment. Importantly, subjects in the SPLUNC1-low group were at significantly increased short- and long-term risk of AE (Hazard ratios: 11.49 at 60 days $\mathrm{p}=0.003$, Figure $4 A)$ and 3.21 at 1 year $(\mathrm{p}=0.013$, Figure $4 B)$.

In order to compare SPLUNC1 to previously reported AE markers as predictors of AE, we defined ROC thresholds and AE-free time for G-CSF, IL1- $\beta$, IL-6, IL-8, and TNF $\alpha$ (Supplemental Figure 3). In a similar multivariate proportional hazards model, cytokine high/low groups based on these markers did not show an increased hazard ratio of $\mathrm{AE}$ at 60 days, and only IL-1 $\beta$ was associated with an AE increased risk at 1 year of follow up (Hazard ratio: 3.90, $\mathrm{p}=0.017$, Supplemental Figure 6). These findings suggest that SPLUNC1 is a better predictor of $\mathrm{AE}$ risk in the short and long term than previously reported sputum markers of $\mathrm{AE}$.

\section{Human and Bacterial Elastases Found in CF Sputum Degrade SPLUNC1}

In order to understand the mechanisms of SPLUNC1 decrease in AE, we first tested the role NE and bacterial elastases increased during AE in SPLUNC1 degradation. We incubated recombinant human SPLUNC1 (rhSPLUNC1) with recombinant human 
medRxiv preprint doi: https://doi.org/10.1101/2020.05.15.20100669; this version posted May 19, 2020. The copyright holder for this preprint

neutrophil elastase (NE) or Pseudomonas aeruginosa's Elastase B (LasB) at increasing concentrations for 3 and 8 hours. NE and Lasb induced a concentration-dependent decrease in full-length SPLUNC1 (Figures 5A, B). Next, we quantified NE concentrations in HC and $\mathrm{CF}$ sputum during stable and $\mathrm{AE}$ periods. NE was increased overall in $\mathrm{CF}$, but it did not increase significantly from stable levels during AE (Figure 5C). Finally, to define subjectspecific NE and SPLUNC1 changes, we performed Western blot of HC and CF sputum and

probed for NE, followed by re-probing for SPLUNC1. SPLUNC1 was decreased in CF in association with increased NE, however, there were no differences in NE or SPLUNC1 between Stable and AE CF sputum (Figure 5D). Our data indicate that NE is important for SPLUNC1 degradation in CF sputum but its concentration does not vary between stable and AE states.

To determine if NE activity, rather than concentration, increased during $\mathrm{AE}$ we measured NE-specific fluorescent cleavage products. When incubated with NE, CF sputum had much higher NE activity than HC sputum; however, there was no difference between stable and AE subjects (Figure 5E).

\section{SPLUNC1 Expression is Decreased by AE-Associated Cytokines}

To further define the AE inflammatory profile of $\mathrm{CF}$ subjects, we measured inflammatory cytokines in the sputum of stable and AE subjects. When comparing CF disease states, only IL-1 $\beta$ and TNF $\alpha$ were significantly increased during AE (Figure 6A). In order to determine if increased IL-1 $\beta$ and TNF $\alpha$ contributed to decreased SPLUNC1 during AE, we treated primary mouse tracheal epithelial cells (mTEC) and the human airway epithelial cell line NCI-H292 with these cytokines and measured SPLUNC1 mRNA 
medRxiv preprint doi: https://doi.org/10.1101/2020.05.15.20100669; this version posted May 19, 2020. The copyright holder for this preprint (which was not certified by peer review) is the author/funder, who has granted medRxiv a license to display the preprint in perpetuity. It is made available under a CC-BY-NC-ND 4.0 International license.

expression. At concentrations encountered in AE sputum, both IL-1 $\beta$ and TNF $\alpha$ decreased SPLUNC1 expression by airway epithelial cells (Figure 6B). Together with our observations from $\mathrm{NE}$ and LasB experiments, these findings suggest that during $\mathrm{AE}$, SPLUNC1 is decreased through protein degradation and cytokine-driven transcriptional regulation 
medRxiv preprint doi: https://doi.org/10.1101/2020.05.15.20100669; this version posted May 19, 2020. The copyright holder for this preprint

\section{DISCUSSION}

AEs contribute to accelerated lung function decline and increased morbidity and mortality in $\mathrm{CF}[5-9,25,26]$. Early $\mathrm{AE}$ detection is crucial in $\mathrm{CF}$ care, however noninvasive inflammatory AE biomarkers are not routinely used in clinical practice. Here, we describe a novel role for SPLUNC1 as a marker and predictor of AE in CF.

Sputum SPLUNC1 is lower in CF overall and further decreased during AE. Importantly, we show that stable subjects with low SPLUNC1 levels have a significantly increased likelihood of $\mathrm{AE}$ in the short and long term. These findings suggest that SPLUNC1 levels could inform the diagnosis and clinical management of AE.

The relationship between airway infection, lung inflammation, and lung function decline in $\mathrm{CF}$ has been studied in detail [27-29]. In the context of acute airway inflammation, SPLUNC1 decreased within three hours after exposure to airway proteases, and its expression decreased within 24 hours in response to inflammatory cytokines. Pathogens could also decrease SPLUNC1 during AE, as shown here with LasB, an extracellular PA protease detected in CF sputum [30]. Thus, synergistic degradation by inflammatory cells and bacteria, and transcriptional downregulation by IL-1 $\beta$ and TNF $\alpha$ decrease SPLUNC1 as a terminal result of immune activation during AE.

We observed subject-specific SPLUNC1 decreases during AE. This supports measuring baseline levels longitudinally in CF to define a SPLUNC1 baseline before and after development of new respiratory symptoms. This longitudinal baseline could account for daily SPLUNC1 fluctuations related to environmental exposures. Daily SPLUNC1 variations can be differentiated from AE through their dose-effect regulation. For example, basal pathogen and cytokine signals modestly suppress SPLUNC1 levels at baseline. In 
medRxiv preprint doi: https://doi.org/10.1101/2020.05.15.20100669; this version posted May 19, 2020. The copyright holder for this preprint

mouse models lacking these suppressive signals (i.e. IFN $\gamma$ receptor-deficient, Toll-like receptor 4-deficient, and TLR adaptor molecule MyD88-deficient mice) SPLUNC1 levels are dramatically increased[15]. While daily changes in inflammatory signals or pathogen exposures may cause small fluctuations, SPLUNC1 changes during AE occur rapidly and in much greater magnitude (Figures 2, 3). Thus, even in the absence of day-to-day measurements, SPLUNC1 can be a helpful tool to diagnose early or imminent AE.

Low SPLUNC1 levels in stable subjects may also contribute to pathogenesis. SPLUNC1 has host protective functions relevant to $\mathrm{CF}$, including regulation of airway surface liquid, antimicrobial properties, and immunomodulatory effects [31-37]. For example, SPLUNC1 gene polymorphisms causing lower SPLUNC1 levels were recently linked to severe lung function impairments in CF [38]. Although we did not focus on understanding how low SPLUNC1 levels increase AE risk, we interpret that SPLUNC1 cleavage by proteases at functional sites may disrupt its host defense functions[39, 40].

Our study has several limitations. First, we use of a cross-sectional study to develop longitudinal predictions, however this approach enabled us to predict AE in the short and long term with statistically significant findings. Second, our study has a relatively small size, however, our findings show that it was adequately powered to demonstrate differences in key observations that were confirmed on a validation cohort. Finally, although we did not detect differences in stable SPLUNC1 levels between subjects of different CFTR genotypes, our AE study population did have a higher prevalence of advanced lung disease and CF-causing mutations linked to severe disease. We addressed this by using multivariate models to demonstrate that the predictive ability of SPLUNC1 is not affected by these variables. Larger prospective studies are needed to replicate our findings in regards to non- 
F508del genotype cohorts, presence of specific CF comorbidities, and the impact of combined CFTR modulator therapies.

Our findings suggest that SPLUNC1 levels could inform clinical decision-making early in the development of $\mathrm{AE}$, when airway inflammation has not yet translated into detectable lung function decline, overcoming a key limitation of $\mathrm{FEV}_{1}$ measurements for the diagnosis of AE. As novel CF therapies become available, noninvasive and airwayrelevant biomarkers like SPLUNC1 may be useful for clinical trial candidate recruitment and longitudinal assessments of lung disease control that inform the care of our CF population. 


\section{TABLES}

Table 1. Yale Cohort - Demographics

Number of Patients ( $n)$

$H C$ (9)

CF Stable (30) AE (14)

Age

Age (Mean)

33.5

41.1

32.1

Age (STD)

10.7

17.0

6.4

Age (Range)

$27-45$

20-79

$23-43$

Sex

Female (n)

Female (\%)

Male (n)

Male (\%)

Mutation Background

F508del/F508del (n)

F508del/F508del (\%)

F508del/other (n)

F508del/other (\%)

Other mutations (n)

Other mutations (\%)
$N A$

$N A$

$N A$

$N A$

$N A$

$N A$

$\mathrm{FEV}_{1}(\mathrm{~L})$
11.1

8

88.9

43.3
8

57.1

6

42.9 


\begin{tabular}{|c|c|c|c|}
\hline $\mathrm{FEV}_{1}(\mathrm{STD})$ & $N A$ & 0.7 & 0.7 \\
\hline $\mathrm{FEV}_{1}$ (Range) & $N A$ & $0.57-3.3$ & $0.55-2.98$ \\
\hline \multicolumn{4}{|l|}{$\mathrm{FEV}_{1}(\%)$} \\
\hline $\mathrm{FEV}_{1}$ (Mean) & $N A$ & 67.5 & 56.1 \\
\hline $\mathrm{FEV}_{1}(\mathrm{STD})$ & $N A$ & 24.3 & 24.3 \\
\hline $\mathrm{FEV}_{1}$ (Range) & $N A$ & $12-121$ & $12-89$ \\
\hline \multicolumn{4}{|l|}{$\mathrm{BMI}\left(\mathrm{Kg} / \mathrm{m}^{2}\right)$} \\
\hline BMI (Mean) & $N A$ & 24.4 & 22.7 \\
\hline BMI (STD) & $N A$ & 4.1 & 4 \\
\hline BMI (Range) & $N A$ & $17.6-35.8$ & $17.6-35.8$ \\
\hline
\end{tabular}

Exacerbations per year (AE/y)

AE/y (Mean)

AE/y (Range)

CF Comorbidities

PI (n)

PI $(\%)$

CFRD (n)

CFRD (\%)

Microbiology

PA Colonization (n)

PA Colonization (\%)
$N A$

1.9

3.7

$N A$

0-10

$1-10$ 


$\begin{array}{llll}\text { Ivacaftor (n) } & N A & 2 & 0 \\ \text { Ivacaftor (\%) } & N A & 6.7 & 0 \\ \text { Ivacaftor/Lumacaftor (n) } & N A & 6 & 7 \\ \text { Ivacaftor/Lumacaftor (\%) } & N A & 20 & 50\end{array}$

FOOTER: Table 1: Demographic characteristics of the Yale Adult CF Program cohort (Discovery Cohort). HC: Healthy controls; CF Stable: CF subjects without exacerbation; AE: Subjects with active exacerbation.

Table 2. University of Minnesota Cohort - Demographics

Age

Age (Mean)

Age (STD)

Age (Range)

Sex

Female (n)

Female (\%)

Male (n)

Male (\%)

Mutation Background
CF Stable (11) AE (24)

27.1

30.0

7.7

10.5

$14-40$

$13-57$ 
F508del/F508del (n)

F508del/F508del (\%)

F508del/other (n)

F508del/other (\%)

Other mutations (n)

Other mutations $(\%)$

$\mathrm{FEV}_{1}(\mathrm{~L})$

$\mathrm{FEV}_{1}($ Mean)

$\mathrm{FEV}_{1}(\mathrm{STD})$

$\mathrm{FEV}_{1}$ (Range)

$\mathrm{FEV}_{1}(\%)$

$\mathrm{FEV}_{1}$ (Mean)

$\mathrm{FEV}_{1}(\mathrm{STD})$

$\mathrm{FEV}_{1}$ (Range)

BMI

BMI (Mean)

BMI (STD)

BMI (Range)

Exacerbations per year (AE/y)

4.1

4.3

AE/y (Range)

$1-12$

$1-10$

45.3

14.1

26-74

21.3

3.1

$13.1-25.8$

\section{CF Comorbidities}


PI (n)

PI $(\%) \quad 100 \quad 95.8$

CFRD (n)

6

9

CFRD $(\%)$

54.5

37.5

Microbiology

PA Colonization (n)

5

9

PA Colonization (\%)

45.5

37.5

CFTR Modulators

Ivacaftor (n)

0

0

Ivacaftor $(\%)$

0

0

Ivacaftor/Lumacaftor (n)

0

0

Ivacaftor/Lumacaftor (\%)

0

0

FOOTER: Table 2: Demographic characteristics of the University of Minnesota CF Center cohort (Validation Cohort). CF Stable: CF subjects without exacerbation; AE: Subjects with active exacerbation. 


\section{FIGURE LEGENDS}

\section{Figure 1. SPLUNC1 is Decreased in the Sputum of Stable CF Subjects. A) SPLUNC1}

levels (ELISA) in sputum samples from the Yale cohort of adult CF subjects without respiratory symptoms (CF Stable) and healthy controls (HC). B) Total protein in sputum (BCA assay) from the same subjects. C) Inflammatory cytokine levels (ELISA) in sputum from the same subjects. Additional cytokines tested without significant difference: CXCL10, G-CSF, IFN $\lambda$, IL-6, IL-13, MCP1, MIP1 $\alpha$. CF Samples were obtained by voluntary expectoration during clinical assessment, $\mathrm{HC}$ samples obtained by sputum induction with nebulized normal saline solution. $+=$ Mean; Bar inside box: Median; Whiskers: Minimum/Maximum. Mann-Whitney Test with Bonferroni correction; * = $p<0.05 ; * *=p<0.01 ; * * * *=p<0.0001$.

Figure 2. SPLUNC1 is Decreased During Acute CF Exacerbations (AE). Sputum SPLUNC1 and $\mathrm{FEV}_{1}$ from two clinical cohorts including adult (Yale University, n=44) and mixed adult/pediatric (University of Minnesota, $n=35$ ) CF subjects. Samples were obtained by voluntary expectoration during clinical assessment, A) SPLUNC1 quantified by ELISA, B) $\mathrm{FEV}_{1}$ (Percent of Predicted, \%) obtained by spirometry during clinical assessment; $C F$ Stable: No symptoms of AE, no antibiotic treatment. AE: Acute CF exacerbation, symptoms of $A E$ and ongoing antibiotic therapy; $F E V_{1}$ : Forced Expiratory Volume in the first second; + = Mean; Bar inside box: Median; Whiskers: Minimum/Maximum. Mann-Whitney test; ** $=p<0.005 ; * * *=p<0.001 ;$ ns $=$ not statistically significant . 
medRxiv preprint doi: https://doi.org/10.1101/2020.05.15.20100669; this version posted May 19, 2020. The copyright holder for this preprint (which was not certified by peer review) is the author/funder, who has granted medRxiv a license to display the preprint in perpetuity.

It is made available under a CC-BY-NC-ND 4.0 International license .

Figure 3. Subject-Specific SPLUNC1 and $\mathrm{FEV}_{1}$ Decreases During AE. A) Paired SPLUNC1 levels in sputum samples from the same individual with and without AE (ELISA); B) Paired $\mathrm{FEV}_{1}$ measurements from the same individual with and without $\mathrm{AE}$ (Percent of Predicted, \%) obtained by spirometry during clinical assessment; Samples from two clinical cohorts including adult (Yale University, $n=8$ ) and mixed adult/pediatric CF subjects (University of Minnesota, $n=11$ ). Each vertical line and number represent a single subject that provided one Stable and one AE sample. CF Stable (Gray markers): No symptoms of AE, no antibiotic treatment. AE (Red markers): Acute CF Exacerbation, symptoms of $A E$ and ongoing antibiotic therapy; When values were the same, these were represented by two overlapping diamonds along the subject's line. Wilcoxon matched-pairs signed rank test $; *=p<0.05, * * *=p=0.0001$, ns=not statistically significant .

Figure 4. SPLUNC1 Predicts AE-Free Time. A) AE-Free time in Stable CF subjects separated into SPLUNC1-High and SPLUNC1-Low groups over a 60-day follow up period. SPLUNC1-high and -low groups were defined according to sputum concentration thresholds obtained from ROCs separating CF Stable and AE levels (Supplemental Figure 3). AE-Free time was defined as the number of days from sputum collection in Stable subjects until the date of their next AE. B) AE-Free time in Stable CF subjects separated into SPLUNC1-High and -Low groups over a 365-day follow up period. Cox Proportional Hazards model used to calculate AE-free intervals and adjust for age, sex, BMI, FEV 1 , number of F508del mutations, presence of CF-related diabetes or pancreatic insufficiency, use of CFTR modulators, and microbiology for $P$. aeruginosa, A. xylosoxidans, $H$. parainfluenzae, Methicillin-sensitive S. aureus, and Methicillin-resistant S. aureus. 
medRxiv preprint doi: https://doi.org/10.1101/2020.05.15.20100669; this version posted May 19, 2020. The copyright holder for this preprint (which was not certified by peer review) is the author/funder, who has granted medRxiv a license to display the preprint in perpetuity.

It is made available under a CC-BY-NC-ND 4.0 International license .

Figure 5. Elastase Concentration and Activity are Increased in CF. A) SPLUNC1 densitometry showing degradation by human neutrophil elastase (NE) relative to PBS control, at specified concentrations over 3 hours at $37^{\circ} \mathrm{C}$. B) SPLUNC1 densitometry showing degradation by Elastase B (LasB) from $P$. aeruginosa relative to PBS control at specified concentrations over 8 hours at $37^{\circ} \mathrm{C}$. C) NE densitometry in sputum from healthy controls (HC), Stable CF subjects (CF Stable), and AE subjects (AE) assessed by immunoblot. D) Representative blots showing endogenous expression of SPLUNC1 (25 $\mathrm{kD})$ and $\mathrm{NE}(25-30 \mathrm{kD})$ in $\mathrm{HC}$ and $\mathrm{CF}$ sputum samples from the same individual. Membranes were probed for NE prior to stripping and re-probing for SPLUNC1. E) NE Activity in CF sputum: AMC formation from florigenic NE substrate MAA-3133 following $6 \mathrm{~h}$ incubation with $\mathrm{HC}, \mathrm{CF}$ stable, and $\mathrm{AE}$ sputum at $37^{\circ} \mathrm{C}$. For experiments in $A$ and $B: n$ = 4-5, 2 individual experiments; Mann-Whitney Test; + = Mean; Bar inside box: Median; Whiskers: Minimum/Maximum; $* p<0.05 ; * *=p<0.01 ; * * *=p<0.005 ;$ ns: not statistically significant; HC: Healthy Control; ST: Stable CF; AE: CF exacerbation; m: marker; +ctl: positive control; OD: optic density.

Figure 6. Cytokines IL-1 $\beta$ and TNF- $\alpha$ Increase During AE \& Downregulate SPLUNC1 Expression. A) Inflammatory cytokine levels in sputum from adult CF subjects without respiratory symptoms (CF Stable) and with acute $\mathrm{CF}$ Exacerbation (AE). Additional cytokines tested without significant difference: CXCL10, G-CSF, IFN 22 , IFN $\gamma$, IFN入, IL-6, IL-8, IL-13, MCP1, MIP1 $\alpha$. Mann-Whitney Test with Bonferroni correction. B) Relative SPLUNC1 mRNA expression in mouse tracheal epithelial cells (Mouse epithelium) grown at air-liquid interface and in the NCI-H292 human airway epithelial cell 
medRxiv preprint doi: https://doi.org/10.1101/2020.05.15.20100669; this version posted May 19, 2020. The copyright holder for this preprint

line (Human epithelium) treated with recombinant TNF $\alpha$ and $\mathrm{IL}-1 \beta(10 \mathrm{ng} / \mathrm{mL})$ for 24 hours (n=4-5/condition, 2 experiments, 2-way ANOVA); + = Mean; Bar inside box: Median; Whiskers: Minimum/Maximum; mRNA expression quantified by qPCR. * = $p<0.05 ; * *=p<0.01$.

Supplemental Figure 1. Study design (Yale discovery cohort). Forty-four adult subjects with a confirmed diagnosis of $\mathrm{CF}$ were identified from the Yale Adult CF Program to participate in this study. These patients were recruited during their scheduled routine visits, unscheduled "sick" visits in which they reported new respiratory symptoms, and on their first day of admission to the hospital for treatment of a pulmonary exacerbation (AE). Our recruitment period extended from 2014-2016. We organized study subjects into two groups: 1) Stable CF subjects (CF Stable): Individuals without new respiratory symptoms, who presented to clinic for their scheduled quarterly follow up and, 2) Subjects having an AE: Individuals with new respiratory symptoms, clinically diagnosed with $\mathrm{AE}$ that were prescribed treatment for $\mathrm{AE}$ during scheduled visit, unscheduled sick visit, or first day of hospital admission for AE. All CF subjects provided spontaneously expectorated sputum samples, sputum microbiology samples, and pulmonary function tests. Healthy controls underwent sputum induction. All subjects were followed for the development of AE for one year counted form the date of sputum collection.

\section{Supplemental Figure 2. SPLUNC1 does not change according to F508del genotype.}

SPLUNC1 levels (ELISA) in sputum samples from the Yale cohort of adult CF subjects without respiratory symptoms ( $C F$ Stable) organized by the presence of one, two, or no F508del mutations. Sputum Samples were obtained by voluntary expectoration during 
medRxiv preprint doi: https://doi.org/10.1101/2020.05.15.20100669; this version posted May 19, 2020. The copyright holder for this preprint (which was not certified by peer review) is the author/funder, who has granted medRxiv a license to display the preprint in perpetuity.

It is made available under a CC-BY-NC-ND 4.0 International license.

clinical assessment, + = Mean; Bar inside box: Median; Whiskers: Minimum/Maximum. Mann-Whitney Test with Bonferroni correction; ns = not statistically significant.

Supplemental Figure 3. Receiver Operator Curve Development for defining SPLUNC1, IL-1 $\beta$, TNF $\alpha$, GCSF, IL-6, and IL-8 High and Low categories. Cutoff values (*) were selected to provide maximum sensitivity with the highest specificity possible (highlighted in gray).

\section{Supplemental Figure 4. SPLUNC1 is Decreased During CF Exacerbations Requiring}

Outpatient or Inpatient Antibiotic Treatment. SPLUNC1 levels in sputum samples from

a clinical cohort including adult and pediatric CF subjects (University of Minnesota). Samples were obtained by voluntary expectoration during clinical assessment, SPLUNC1 quantified by ELISA. $C F$ Stable: No symptoms of AE, no antibiotic treatment. $A E$ Outpatient (AE OP): Clinical symptoms consistent with exacerbation, treated with oral antibiotics at the time of sputum collection. $A E$ Inpatient $(A E I P)$ : Admitted for inpatient antibiotic course, sample collected during first day of treatment. + = Mean; Bar inside box: Median; Whiskers: Minimum/Maximum; Mann-Whitney test; $*=p<0.05$, $* *=p<0.01, n s$ = not statistically significant.

\section{Supplemental Figure 5. SPLUNC1 Predicts AE-Free Time (unadjusted survival} model). A) Stable CF subjects were separated into SPLUNC1-high and SPLUNC1-Low groups according to a SPLUNC1 threshold of $2334 \mathrm{ng} / \mathrm{mL}$. Time to AE in days was measured over 365 days from the date of sputum collection in all subjects. B) Stable 
medRxiv preprint doi: https://doi.org/10.1101/2020.05.15.20100669; this version posted May 19, 2020. The copyright holder for this preprint (which was not certified by peer review) is the author/funder, who has granted medRxiv a license to display the preprint in perpetuity.

It is made available under a CC-BY-NC-ND 4.0 International license .

subjects with an $\mathrm{FEV}_{1}>40 \%$ of predicted were separated into SPLUNC1-high and SPLUNC1-low cohorts as above. Time to exacerbation was measured for up to one year from the date of sputum collection. Mantel-Haenszel estimator was used to calculate exacerbation-free interval in each group. Values are not adjusted for clinical variables. Adjusted values from a Cox proportional hazards model are presented in Figure 6. $A E: C F$ exacerbation, HR: Hazard ratio, CI: Confidence interval.

\section{Supplemental Figure 6. Sputum Cytokines Do Not Predict Short Term AE-Free Time.}

(A) AE-Free time in Stable CF subjects separated into IL-1 $\beta-$, TNF $\alpha-$, G-CSF-, IL-6-, and IL-8-High and -Low groups over a 60-day follow up period. Marker-high and -low groups were defined according to sputum concentration thresholds obtained from ROCs separating CF Stable and AE levels (Supplemental Figure 3). AE-Free time was defined as the number of days from sputum collection in Stable subjects until the date of their next AE. (B) AEFree time in Stable CF subjects separated into IL-1 $\beta$-, TNFo-, G-CSF-, IL-6-, and IL-8High and -Low groups over a 365-day follow up period. Cox Proportional Hazards model used to calculate AE-free intervals and adjust for age, sex, BMI, FEV ${ }_{1}$, number of $F 508 d e l$ mutations, presence of CF-related diabetes or pancreatic insufficiency, use of CFTR correctors/modulators, and microbiology for $P$. aeruginosa, A. xylosoxidans, $H$. parainfluenzae, Methicillin-sensitive S. aureus, and Methicillin-resistant S. aureus. HR: Hazard ration; SE: Standard error.

Supplemental Figure 7. Full unedited Western blots for figure 5D. Membranes were initially probed for NE prior to stripping and re-probing for SPLUNC1. A) NE antibody: 
medRxiv preprint doi: https://doi.org/10.1101/2020.05.15.20100669; this version posted May 19, 2020. The copyright holder for this preprint (which was not certified by peer review) is the author/funder, who has granted medRxiv a license to display the preprint in perpetuity.

It is made available under a CC-BY-NC-ND 4.0 International license .

Mouse monoclonal anti-hELA2 raised against residues M1-N252 (1:3000, R\&D systems).

B) SPLUNC1 antibody: goat polyclonal hPLUNC1 antibody raised against residues Q20 V256 of hPLUNC1 (1:3000, R\&D systems), a secondary anti-goat HRP. HC: Healthy

Control; ST: Stable CF; AE: CF exacerbation; m: marker; +ctl: positive control.

\section{ACKNOWLEDGMENTS}

This work was supported by The National Institutes of Health \& National Heart, Lung, and Blood Institute (USA) through grants NIH R01-HL081160 and R21-AI083475 (LC), NIH T32-HL007778 and K01-HL125514-01 (CB), the Cystic Fibrosis Foundation through its Fifth Year Clinical Fellowship Award, and the American Thoracic Society Foundation Unrestricted Research Award (CB). CF Foundation (RT); UK CF Trust (RT). We thank our patients, the medical staff at the Yale Adult Cystic Fibrosis Program, and Dr. Jonathan Koff, Director of the Adult CF Program, for their support and contributions to this project.

We also thank Dr. Mehmet Kesimer from the University of North Carolina at Chapel Hill for his thoughtful review and contributions in the development of this manuscript.

\section{AUTHOR CONTRIBUTIONS}

$\mathrm{CB}, \mathrm{NN}, \mathrm{SK}, \mathrm{LS}$, and CDC planned the project, designed and performed experiments, analyzed the data, and wrote the manuscript. TL and MN, contributed to the design and analysis of clinical data, and provided access to the UMN cohort samples. MW, and RT performed, and analyzed experiments related to NE densitometry and activity in sputum. GC generated the sputum collection protocol for the Yale cohort and facilitated access to 
banked human samples. LC, MS, JLG, ME, and GC contributed to the design and analysis of all experiments, and the final manuscript. MDS provided biostatistics support and analyzed all experiments. All authors reviewed, revised, and approved the manuscript for submission.

\section{DISCLOSURES}

Dr. Tarran reports the following financial and intellectual property disclosures: Eldec Pharmaceuticals, outside the submitted work; In addition, Dr. Tarran has a patent on Peptide inhibitors of $\mathrm{Ca} 2+$ channels pending, a patent on PEPTIDE INHIBITORS OF SODIUM CHANNELS with royalties paid, and a patent on Regulation of sodium channels by PLUNC proteins with royalties paid. Dr. Cohn reports the following financial disclosures: Genentech, Novartis, Astra-Zeneca, GlaxoSmithKline, Regeneron, Pieris, Sanofi, all outside the submitted work. Dr. Laguna reports grants from National Institutes of Health, grants from Cystic Fibrosis Foundation, other from Vertex Physician Advisory Board, outside the submitted work. Dr. Chupp reports from Genentech, other from Astra Zeneca, other from Sanofi - Regeneron, other from GSK, other from TEVA, other from Boehringer-Ingelheim, other from Circassia, outside the submitted work. The other authors of this manuscript do not have any conflicts of interest that could be perceived to bias their work. 
medRxiv preprint doi: https://doi.org/10.1101/2020.05.15.20100669; this version posted May 19, 2020. The copyright holder for this preprint

(which was not certified by peer review) is the author/funder, who has granted medRxiv a license to display the preprint in perpetuity.

It is made available under a CC-BY-NC-ND 4.0 International license .

\section{REFERENCES}

1. Foundation CF. 2018 Annual Data Report. Bethesda, Maryland: Cystic Fibrosis Foundation; 2019.

2. Rowe SM, Miller S, Sorscher EJ. Cystic fibrosis. The New England journal of medicine 2005: 352(19): 1992-2001.

3. Welsh MJ RB, Accurso F, Cutting GR. Cystic Fibrosis. In: Scriver CR BA, Sly WS, Valle D,Childs B,Vogelstein B, ed. The metabolic and molecular basis of inherited disease. 8 ed. McGraw-Hill, 2001; pp. 5121-5189.

4. Collinson J, Nicholson KG, Cancio E, Ashman J, Ireland DC, Hammersley V, Kent J, O'Callaghan C. Effects of upper respiratory tract infections in patients with cystic fibrosis. Thorax 1996: 51(11): 1115-1122.

5. Flight WG, Bright-Thomas RJ, Tilston P, Mutton KJ, Guiver M, Morris J, Webb AK, Jones AM. Incidence and clinical impact of respiratory viruses in adults with cystic fibrosis. Thorax 2014: 69(3): 247-253.

6. Flight WG, Bright-Thomas RJ, Sarran C, Mutton KJ, Morris J, Webb AK, Jones AM. The effect of the weather on pulmonary exacerbations and viral infections among adults with cystic fibrosis. Int J Biometeorol 2014: 58(9): 1845-1851.

7. Goss CH, Burns JL. Exacerbations in cystic fibrosis. 1: Epidemiology and pathogenesis. Thorax 2007: 62(4): 360-367.

8. Pribble CG, Black PG, Bosso JA, Turner RB. Clinical manifestations of exacerbations of cystic fibrosis associated with nonbacterial infections. J Pediatr 1990: 117(2 Pt 1): 200-204.

9. Wark PA, Tooze M, Cheese L, Whitehead B, Gibson PG, Wark KF, McDonald VM. Viral infections trigger exacerbations of cystic fibrosis in adults and children. Eur Respir J 2012: 40(2): 510-512.

10. van Ewijk BE, van der Zalm MM, Wolfs TF, van der Ent CK. Viral respiratory infections in cystic fibrosis. Journal of cystic fibrosis : official journal of the European Cystic Fibrosis Society 2005: 4 Suppl 2: 31-36.

11. Harun SN, Wainwright C, Klein K, Hennig S. A systematic review of studies examining the rate of lung function decline in patients with cystic fibrosis. Paediatric respiratory reviews 2016.

12. Laguna TA, Williams CB, Brandy KR, Welchlin-Bradford C, Moen CE, Reilly CS, Wendt $\mathrm{CH}$. Sputum club cell protein concentration is associated with pulmonary exacerbation in cystic fibrosis. Journal of cystic fibrosis : official journal of the European Cystic Fibrosis Society 2015: 14(3): 334-340.

13. Sagel SD, Kapsner R, Osberg I, Sontag MK, Accurso FJ. Airway Inflammation in Children with Cystic Fibrosis and Healthy Children Assessed by Sputum Induction. American journal of respiratory and critical care medicine 2001: 164(8): 1425-1431.

14. Sagel SD, Wagner BD, Anthony MM, Emmett P, Zemanick ET. Sputum biomarkers of inflammation and lung function decline in children with cystic fibrosis. American journal of respiratory and critical care medicine 2012: 186(9): 857-865.

15. Britto CJ, Liu Q, Curran DR, Patham B, Dela Cruz CS, Cohn L. Short palate, lung, and nasal epithelial clone-1 is a tightly regulated airway sensor in innate and adaptive 
medRxiv preprint doi: https://doi.org/10.1101/2020.05.15.20100669; this version posted May 19, 2020. The copyright holder for this preprint

(which was not certified by peer review) is the author/funder, who has granted medRxiv a license to display the preprint in perpetuity. It is made available under a CC-BY-NC-ND 4.0 International license .

immunity. American journal of respiratory cell and molecular biology 2013: 48(6): 717724.

16. Jiang D, Wenzel SE, Wu Q, Bowler RP, Schnell C, Chu HW. Human neutrophil elastase degrades SPLUNC1 and impairs airway epithelial defense against bacteria. PloS one 2013: 8(5): e64689.

17. Webster MJ, Reidel B, Tan CD, Ghosh A, Alexis NE, Donaldson SH, Kesimer M, Ribeiro CMP, Tarran R. SPLUNC1 degradation by the cystic fibrosis mucosal environment drives airway surface liquid dehydration. Eur Respir J 2018: 52(4).

18. Bingle CD, Bingle L. Characterisation of the human plunc gene, a gene product with an upper airways and nasopharyngeal restricted expression pattern. Biochimica et biophysica acta 2000: 1493(3): 363-367.

19. Britto CJ, Cohn L. Bactericidal/Permeability-increasing protein fold-containing family member A1 in airway host protection and respiratory disease. American journal of respiratory cell and molecular biology 2015: 52(5): 525-534.

20. Yao Y, Welp T, Liu Q, Niu N, Wang X, Britto CJ, Krishnaswamy S, Chupp GL, Montgomery RR. Multiparameter Single Cell Profiling of Airway Inflammatory Cells. Cytometry B Clin Cytom 2017: 92(1): 12-20.

21. Fuchs HJ, Borowitz DS, Christiansen DH, Morris EM, Nash ML, Ramsey BW, Rosenstein BJ, Smith AL, Wohl ME. Effect of aerosolized recombinant human DNase on exacerbations of respiratory symptoms and on pulmonary function in patients with cystic fibrosis. The Pulmozyme Study Group. The New England journal of medicine 1994: 331(10): 637-642.

22. Yan X, Chu JH, Gomez J, Koenigs M, Holm C, He X, Perez MF, Zhao H, Mane S, Martinez FD, Ober C, Nicolae DL, Barnes KC, London SJ, Gilliland F, Weiss ST, Raby BA, Cohn L, Chupp GL. Noninvasive analysis of the sputum transcriptome discriminates clinical phenotypes of asthma. American journal of respiratory and critical care medicine 2015: 191(10): 1116-1125.

23. Laguna TA, Wagner BD, Luckey HK, Mann SA, Sagel SD, Regelmann W, Accurso FJ. Sputum desmosine during hospital admission for pulmonary exacerbation in cystic fibrosis. Chest 2009: 136(6): 1561-1568.

24. Esther CR, Jr., Peden Db Fau - Alexis NE, Alexis Ne Fau - Hernandez ML, Hernandez ML. Airway purinergic responses in healthy, atopic nonasthmatic, and atopic asthmatic subjects exposed to ozone. 2011(1091-7691 (Electronic)).

25. Aaron SD, Ramotar K, Ferris W, Vandemheen K, Saginur R, Tullis E, Haase D, Kottachchi D, St Denis M, Chan F. Adult cystic fibrosis exacerbations and new strains of Pseudomonas aeruginosa. American journal of respiratory and critical care medicine 2004: 169(7): 811-815.

26. Wood RE, Leigh MW. What is a "pulmonary exacerbation" in cystic fibrosis? $J$ Pediatr 1987: 111(6 Pt 1): 841-842.

27. Chen JH, Stoltz Da Fau - Karp PH, Karp Ph Fau - Ernst SE, Ernst Se Fau - Pezzulo AA, Pezzulo Aa Fau - Moninger TO, Moninger To Fau - Rector MV, Rector Mv Fau Reznikov LR, Reznikov Lr Fau - Launspach JL, Launspach Jl Fau - Chaloner K, Chaloner K Fau - Zabner J, Zabner J Fau - Welsh MJ, Welsh MJ. Loss of anion transport without increased sodium absorption characterizes newborn porcine cystic fibrosis airway epithelia. 2010(1097-4172 (Electronic)).

28. Stoltz DA, Meyerholz Dk Fau - Pezzulo AA, Pezzulo Aa Fau - Ramachandran S, Ramachandran S Fau - Rogan MP, Rogan Mp Fau - Davis GJ, Davis Gj Fau - Hanfland 
medRxiv preprint doi: https://doi.org/10.1101/2020.05.15.20100669; this version posted May 19, 2020. The copyright holder for this preprint

(which was not certified by peer review) is the author/funder, who has granted medRxiv a license to display the preprint in perpetuity. It is made available under a CC-BY-NC-ND 4.0 International license .

RA, Hanfland Ra Fau - Wohlford-Lenane C, Wohlford-Lenane C Fau - Dohrn CL, Dohrn Cl Fau - Bartlett JA, Bartlett Ja Fau - Nelson GAt, Nelson Ga 4th Fau - Chang EH, Chang Eh Fau - Taft PJ, Taft Pj Fau - Ludwig PS, Ludwig Ps Fau - Estin M, Estin M Fau Hornick EE, Hornick Ee Fau - Launspach JL, Launspach Jl Fau - Samuel M, Samuel M Fau - Rokhlina T, Rokhlina T Fau - Karp PH, Karp Ph Fau - Ostedgaard LS, Ostedgaard Ls Fau - Uc A, Uc A Fau - Starner TD, Starner Td Fau - Horswill AR, Horswill Ar Fau Brogden KA, Brogden Ka Fau - Prather RS, Prather Rs Fau - Richter SS, Richter Ss Fau Shilyansky J, Shilyansky J Fau - McCray PB, Jr., McCray Pb Jr Fau - Zabner J, Zabner J Fau - Welsh MJ, Welsh MJ. Cystic fibrosis pigs develop lung disease and exhibit defective bacterial eradication at birth. 2010(1946-6242 (Electronic)).

29. Stoltz DA, Meyerholz DK, Welsh MJ. Origins of Cystic Fibrosis Lung Disease. New England Journal of Medicine 2015: 372(16): 1574-1575.

30. Barthe C, Nandakumar S, Derlich L, Macey J, Bui S, Fayon M, Crouzet M, Garbay B, Vilain S, Costaglioli P. Exploring the expression of Pseudomonas aeruginosa genes directly from sputa of cystic fibrosis patients. Lett Appl Microbiol 2015: 61(5): 423-428.

31. Bingle CD, Craven CJ. PLUNC: a novel family of candidate host defence proteins expressed in the upper airways and nasopharynx. Human molecular genetics 2002: 11(8): 937-943.

32. Chu HW, Thaikoottathil J, Rino JG, Zhang G, Wu Q, Moss T, Refaeli Y, Bowler R, Wenzel SE, Chen Z, Zdunek J, Breed R, Young R, Allaire E, Martin RJ. Function and regulation of SPLUNC1 protein in Mycoplasma infection and allergic inflammation. $J$ Immunol 2007: 179(6): 3995-4002.

33. Gakhar L, Bartlett JA, Penterman J, Mizrachi D, Singh PK, Mallampalli RK, Ramaswamy S, McCray PB, Jr. PLUNC is a novel airway surfactant protein with antibiofilm activity. PloS one 2010: 5(2): e9098.

34. Gally F, Di YP, Smith SK, Minor MN, Liu Y, Bratton DL, Frasch SC, Michels NM, Case SR, Chu HW. SPLUNC1 promotes lung innate defense against Mycoplasma pneumoniae infection in mice. The American journal of pathology 2011: 178(5): 21592167.

35. Garcia-Caballero A, Rasmussen JE, Gaillard E, Watson MJ, Olsen JC, Donaldson $\mathrm{SH}$, Stutts MJ, Tarran R. SPLUNC1 regulates airway surface liquid volume by protecting $\mathrm{ENaC}$ from proteolytic cleavage. Proceedings of the National Academy of Sciences of the United States of America 2009: 106(27): 11412-11417.

36. McGillivary G, Bakaletz LO. The multifunctional host defense peptide SPLUNC1 is critical for homeostasis of the mammalian upper airway. PloS one 2010: 5(10): e13224.

37. Britto CJ, Niu N, Khanal S, Huleihel L, Herazo-Maya JD, Thompson A, Sauler M, Slade MD, Sharma L, Dela Cruz CS, Kaminski N, Cohn LE. BPIFA1 regulates lung neutrophil recruitment and interferon signaling during acute inflammation. American journal of physiology Lung cellular and molecular physiology 2019: 316(2): L321-L333.

38. Saferali A, Obeidat M, Berube JC, Lamontagne M, Bosse Y, Laviolette M, Hao K, Nickle DC, Timens W, Sin DD, Postma DS, Strug LJ, Gallins PJ, Pare PD, Bingle CD, Sandford AJ. Polymorphisms Associated with Expression of BPIFA1/BPIFB1 and Lung Disease Severity in Cystic Fibrosis. American journal of respiratory cell and molecular biology 2015.

39. Walton WG, Ahmad S, Little MS, Kim CS, Tyrrell J, Lin Q, Di YP, Tarran R, Redinbo MR. Structural Features Essential to the Antimicrobial Functions of Human SPLUNC1. Biochemistry 2016: 55(21): 2979-2991. 
medRxiv preprint doi: https://doi.org/10.1101/2020.05.15.20100669; this version posted May 19, 2020. The copyright holder for this preprint (which was not certified by peer review) is the author/funder, who has granted medRxiv a license to display the preprint in perpetuity. It is made available under a CC-BY-NC-ND 4.0 International license .

40. Ning F, Wang C, Berry KZ, Kandasamy P, Liu H, Murphy RC, Voelker DR, Nho CW, Pan CH, Dai S, Niu L, Chu HW, Zhang G. Structural characterization of the pulmonary innate immune protein SPLUNC1 and identification of lipid ligands. FASEB journal : official publication of the Federation of American Societies for Experimental Biology 2014: 28(12): 5349-5360. 
medRxiv preprint doi: https://doi.org/10.1101/2020.05.15.20100669; this version posted May 19, 2020. The copyright holder for this preprint (which was not certified by peer review) is the author/funder, who has granted medRxiv a license to display the preprint in perpetuity.

It is made available under a CC-BY-NC-ND 4.0 International license .

A

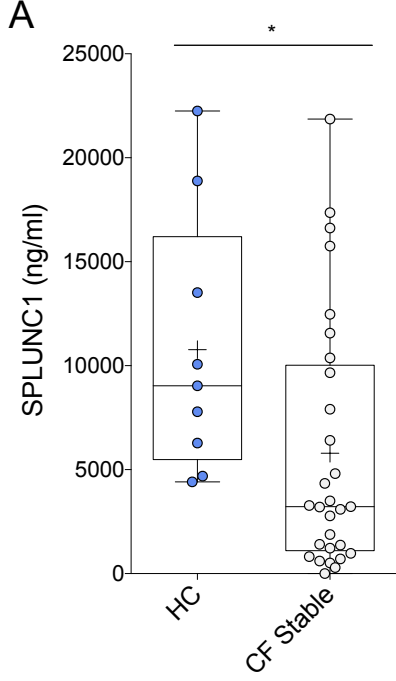

B

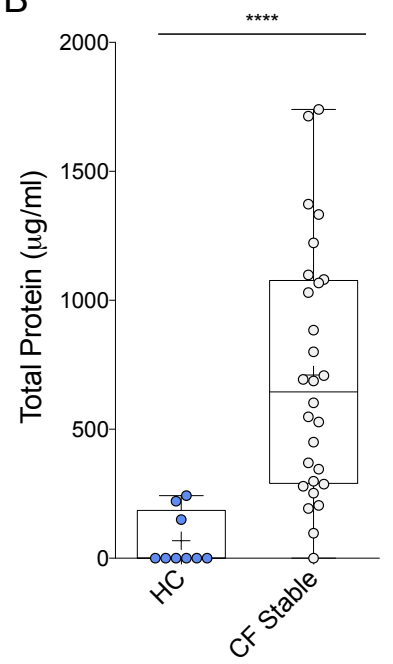

C
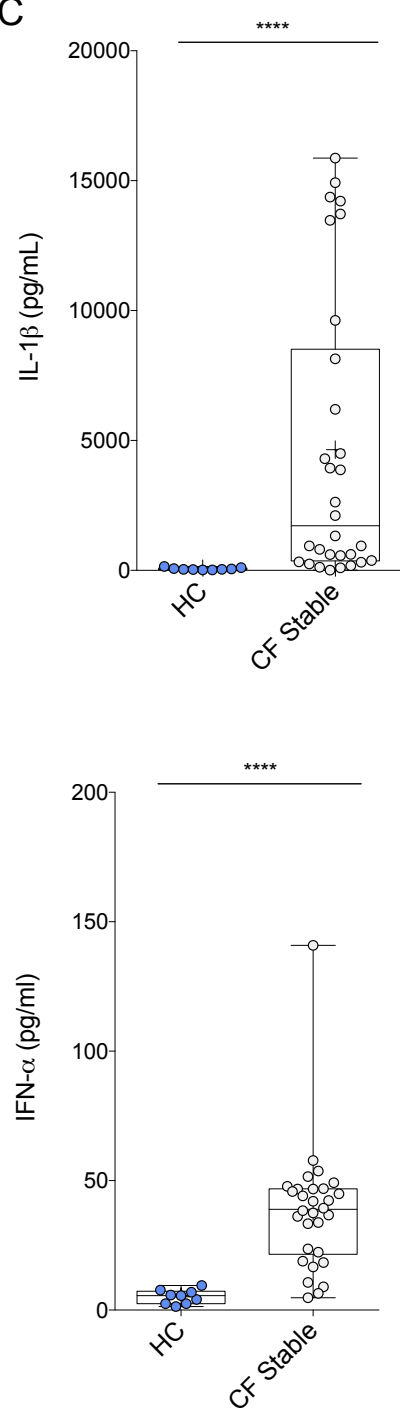
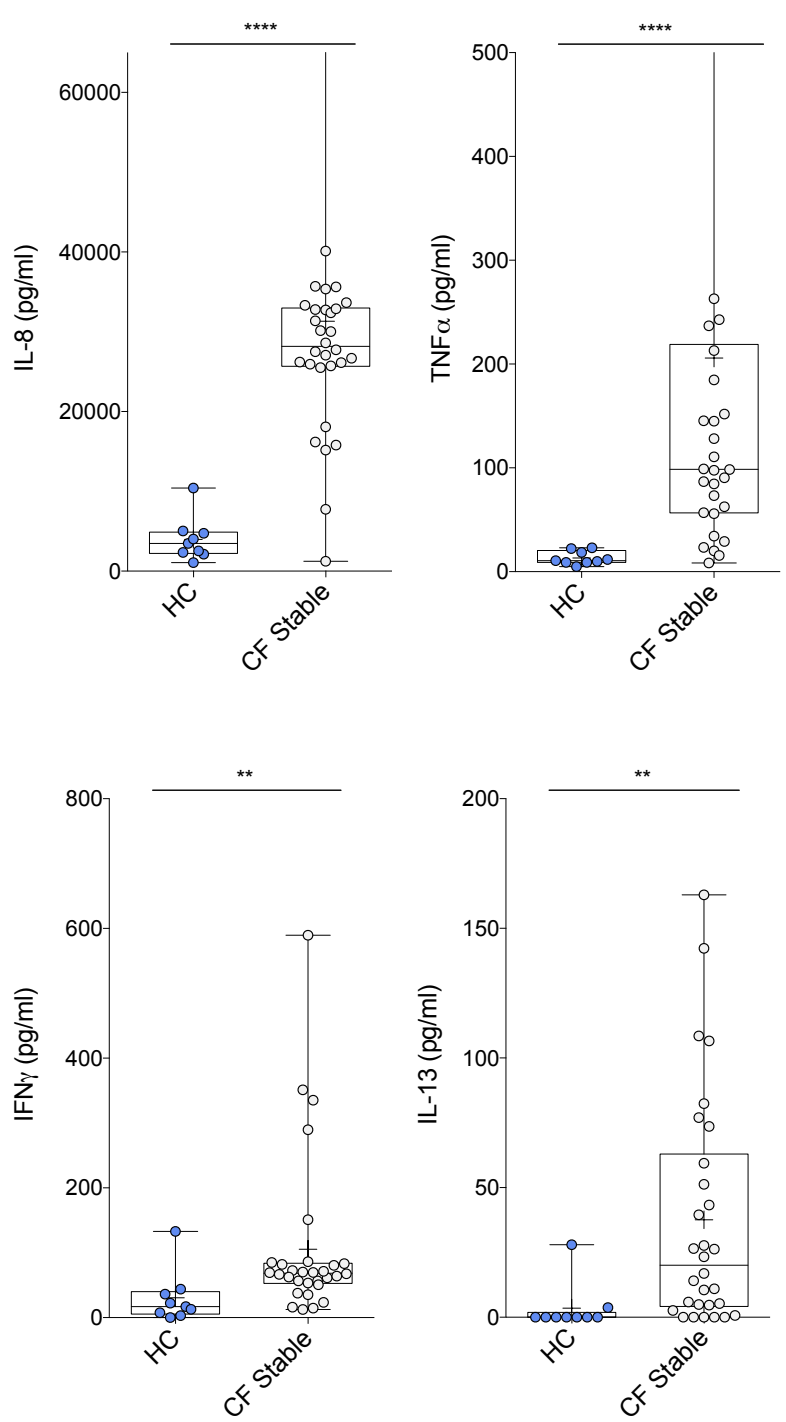

Figure 1. SPLUNC1 is Decreased in the Sputum of Stable CF Subjects. A) SPLUNC1 levels (ELISA) in sputum samples from the Yale cohort of adult CF subjects without respiratory symptoms (CF Stable) and healthy controls $(\mathrm{HC})$. B) Total protein in sputum (BCA assay) from the same subjects. C) Inflammatory cytokine levels (ELISA) in sputum from the same subjects. Additional cytokines tested without significant difference: CXCL10, G-CSF, IFN $\lambda$, IL-6, IL-13, MCP1, MIP1 $\alpha$. CF Samples were obtained by voluntary expectoration during clinical assessment, HC samples obtained by sputum induction with nebulized normal saline solution. + = Mean; Bar inside box: Median; Whiskers: Minimum/Maximum. Mann-Whitney Test with Bonferroni correction; ${ }^{*}=p<0.05 ;{ }^{* *}=p<0.01 ;{ }^{* * * *}=$ $p<0.0001$. 
medRxiv preprint doi: https://doi.org/10.1101/2020.05.15.20100669; this version posted May 19, 2020. The copyright holder for this preprint (which was not certified by peer review) is the author/funder, who has granted medRxiv a license to display the preprint in perpetuity.

It is made available under a CC-BY-NC-ND 4.0 International license .

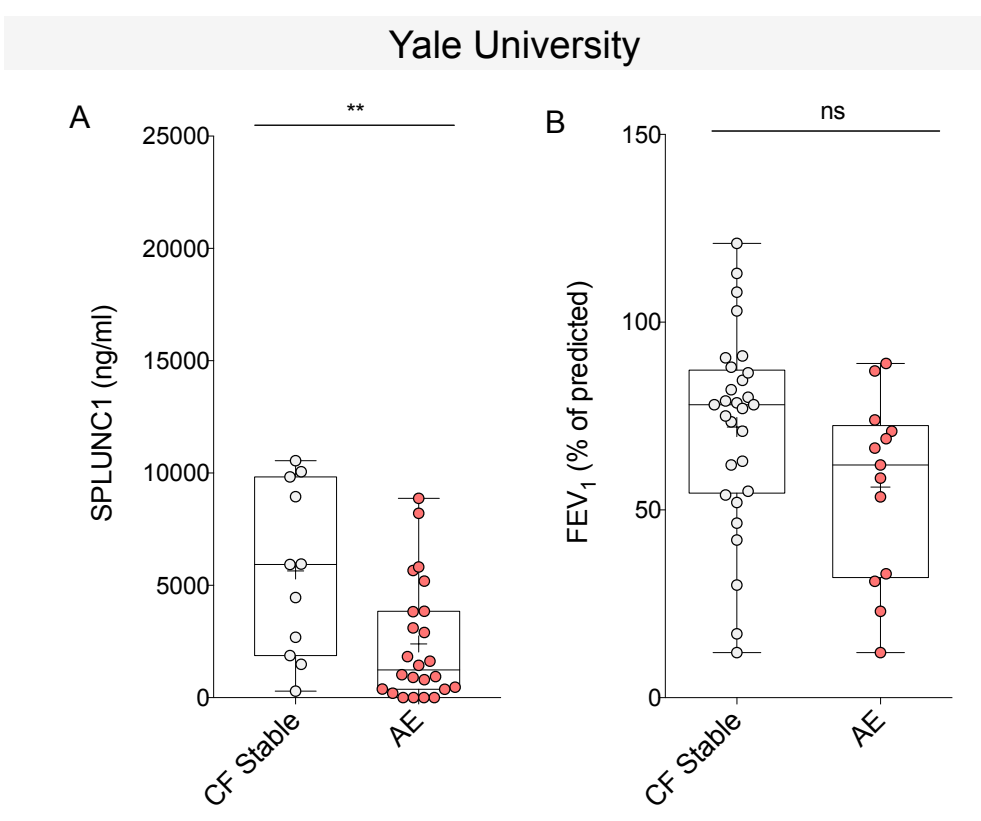

\section{University of Minnesota}

A

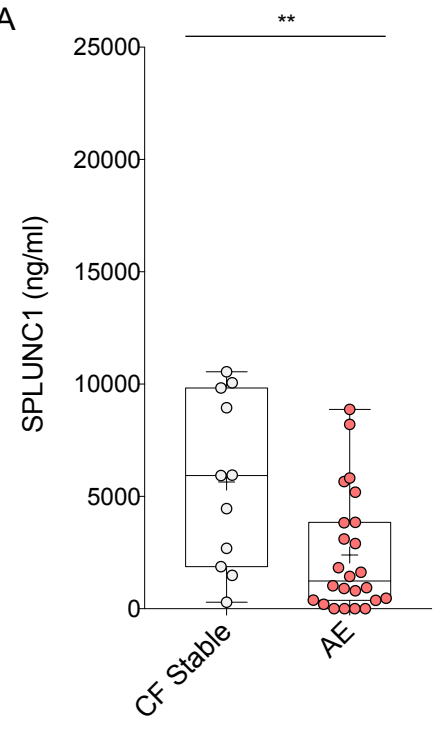

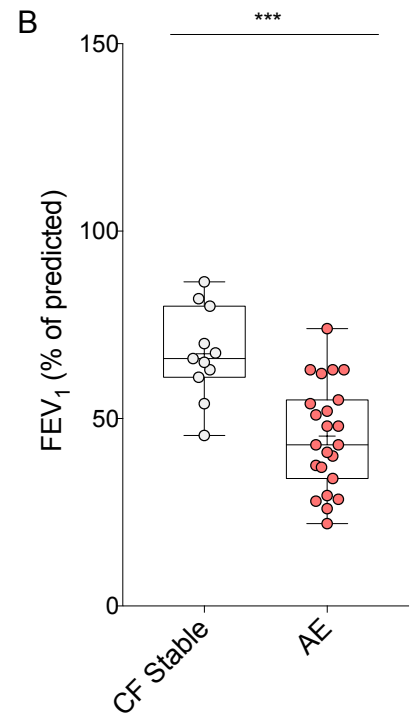

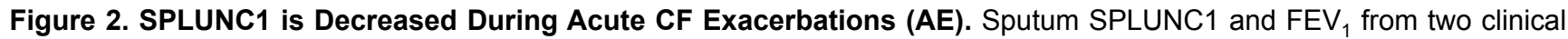
cohorts including adult (Yale University, $n=43$ ) and mixed adult/pediatric (University of Minnesota, $n=35$ ) $C F$ subjects. Samples were obtained by voluntary expectoration during clinical assessment, A) SPLUNC1 quantified by ELISA, B) FEV 1 (Percent of Predicted, \%) obtained by spirometry during clinical assessment; CF Stable: No symptoms of AE, no antibiotic treatment. AE: Acute CF exacerbation, symptoms of AE and ongoing antibiotic therapy; FEV ${ }_{1}$ : Forced Expiratory Volume in the first second; + = Mean; Bar inside box: Median; Whiskers: Minimum/Maximum. Mann-Whitney test; ${ }^{* *}=p<0.005 ;{ }^{* * *}=$ $p<0.001 ; n s=$ not statistically significant. 
medRxiv preprint doi: https://doi.org/10.1101/2020.05.15.20100669; this version posted May 19, 2020. The copyright holder for this preprint (which was not certified by peer review) is the author/funder, who has granted medRxiv a license to display the preprint in perpetuity.

It is made available under a CC-BY-NC-ND 4.0 International license .

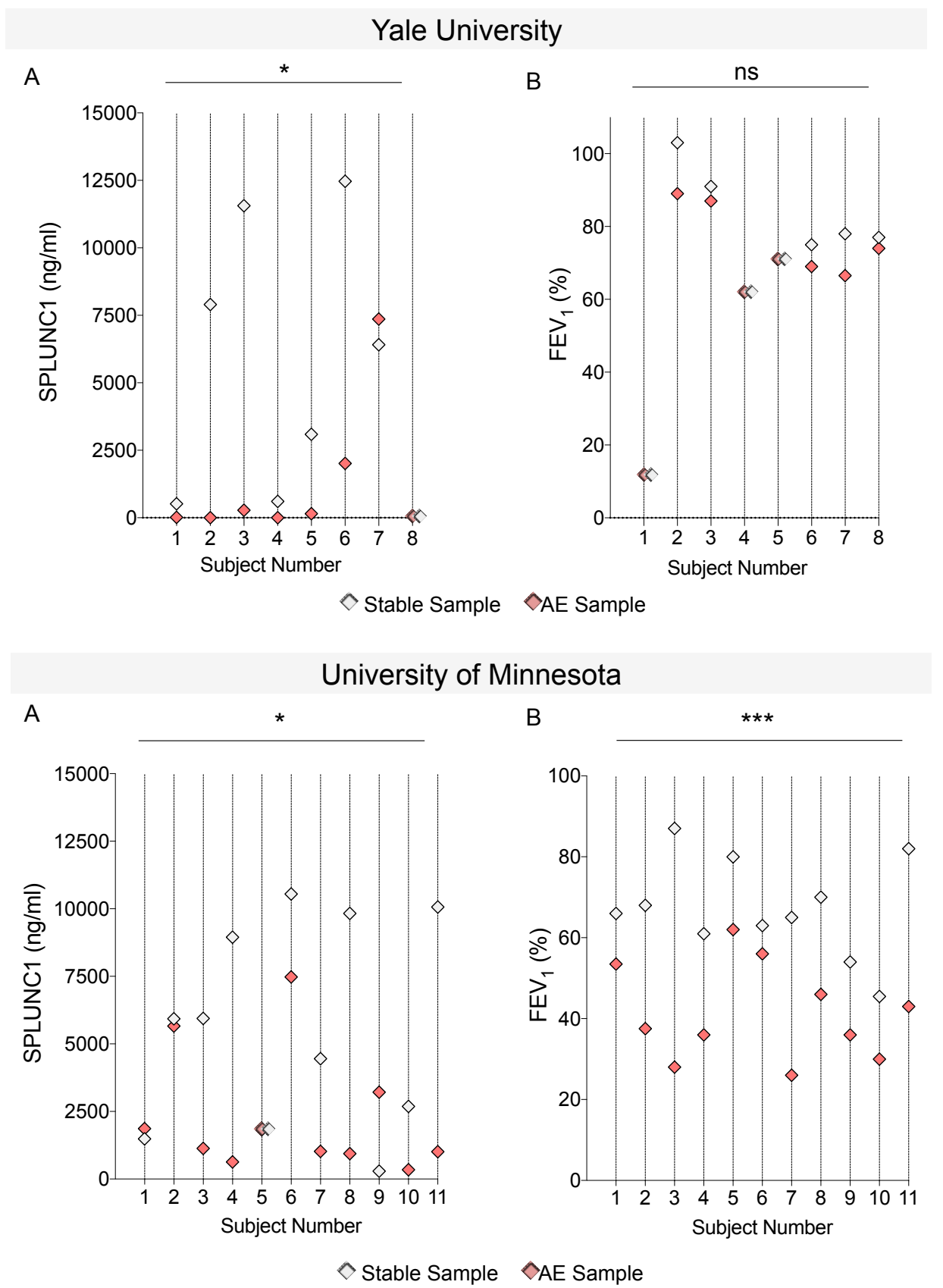

Figure 3. Subject-Specific SPLUNC1 and FEV 1 Decreases During AE. A) Paired SPLUNC1 levels in sputum samples from the same individual with and without AE (ELISA); B) Paired FEV 1 measurements from the same individual with and without AE (Percent of Predicted, \%) obtained by spirometry during clinical assessment; Samples from two clinical cohorts including adult (Yale University, $n=8$ ) and mixed adult/pediatric CF subjects (University of Minnesota, $\mathrm{n}=11$ ). Each vertical line and number represent a single subject that provided one Stable and one AE sample. CF Stable (Gray markers): No symptoms of AE, no antibiotic treatment. AE (Red markers): Acute CF Exacerbation, symptoms of $A E$ and ongoing antibiotic therapy; When values were the same, these were represented by two overlapping diamonds along the subject's line. Wilcoxon matched-pairs signed rank test; ${ }^{*}=p<0.05,{ }^{* * *}=p=0.0001$, ns=not statistically significant. 
medRxiv preprint doi: https://doi.org/10.1101/2020.05.15.20100669; this version posted May 19, 2020. The copyright holder for this preprint (which was not certified by peer review) is the author/funder, who has granted medRxiv a license to display the preprint in perpetuity.

It is made available under a CC-BY-NC-ND 4.0 International license .

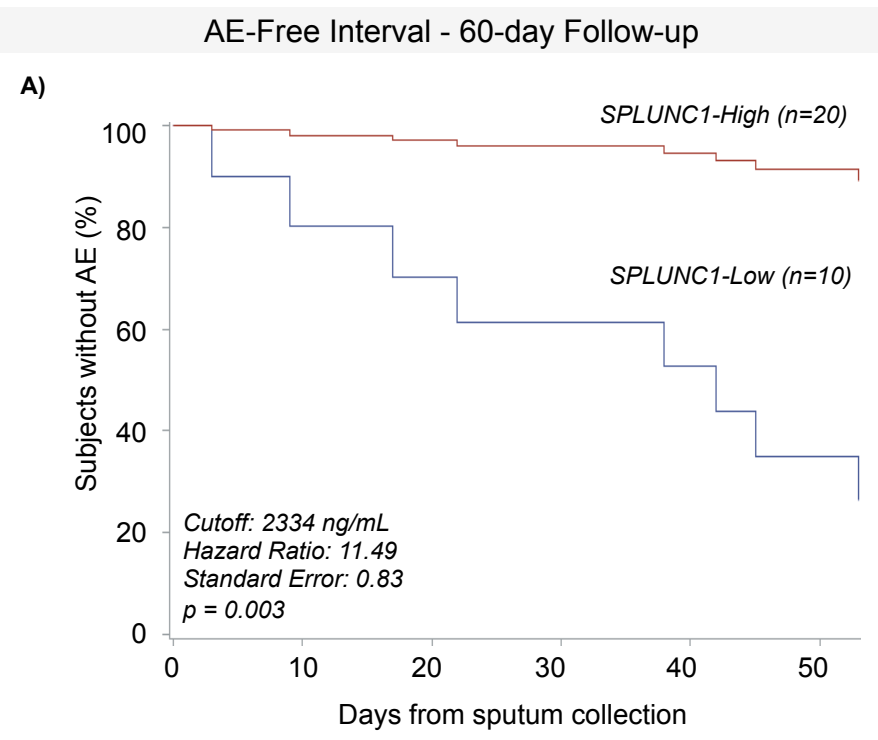

AE-Free Interval - 365-day Follow-up

B)

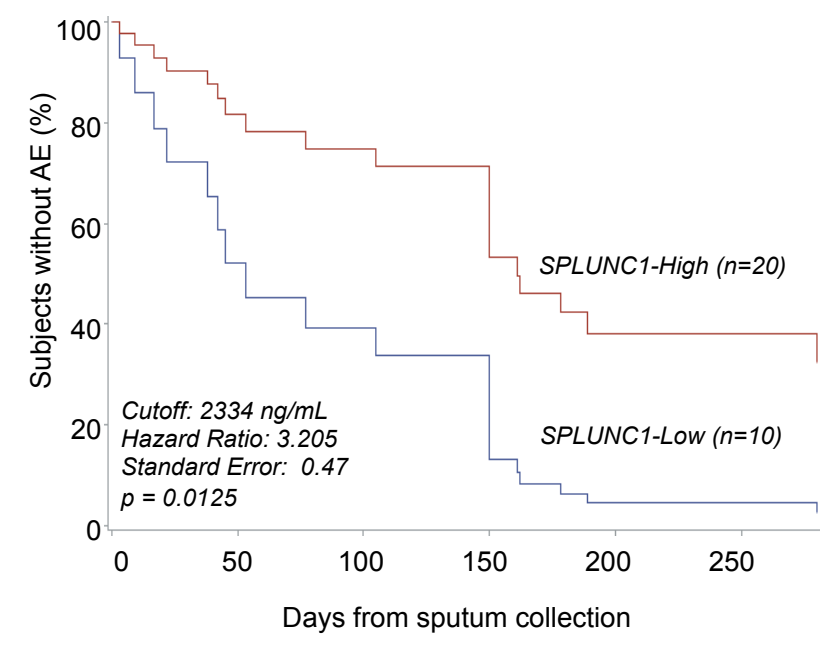

Figure 4. SPLUNC1 Predicts AE-Free Time. A) AE-Free time in Stable CF subjects separated into SPLUNC1-High and SPLUNC1-Low groups over a 60-day follow up period. SPLUNC1-high and -low groups were defined according to sputum concentration thresholds obtained from ROCs separating CF Stable and AE levels (Supplemental Figure 3). $\mathrm{AE}-F$ ree time was defined as the number of days from sputum collection in Stable subjects until the date of their next AE. B) AE-Free time in Stable CF subjects separated into SPLUNC1-High and -Low groups over a 365-day follow up period. Cox Proportional Hazards model used to calculate AE-free intervals and adjust for age, sex, BMI, FEV ${ }_{1}$, number of F508del mutations, presence of CF-related diabetes or pancreatic insufficiency, use of CFTR modulators, and microbiology for $P$. aeruginosa, $A$. xylosoxidans, $H$. parainfluenzae, Methicillin-sensitive $S$. aureus, and Methicillinresistant $S$. aureus. 
medRxiv preprint doi: https://doi.org/10.1101/2020.05.15.20100669; this version posted May 19, 2020. The copyright holder for this preprint (which was not certified by peer review) is the author/funder, who has granted medRxiv a license to display the preprint in perpetuity.

It is made available under a CC-BY-NC-ND 4.0 International license .

A
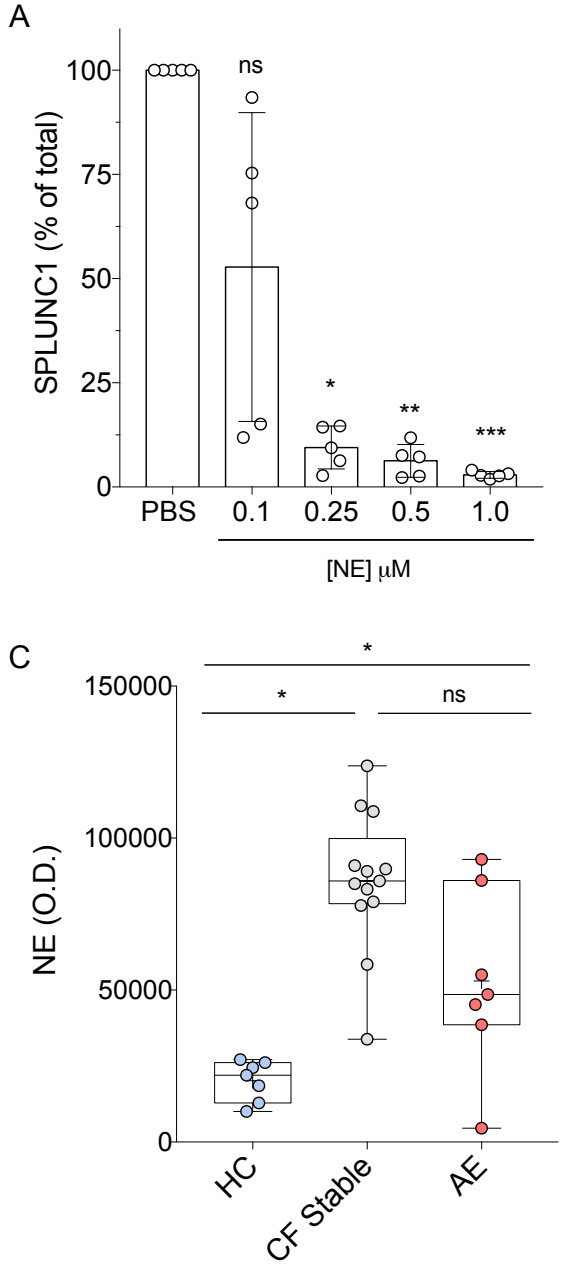

$\mathrm{E}$

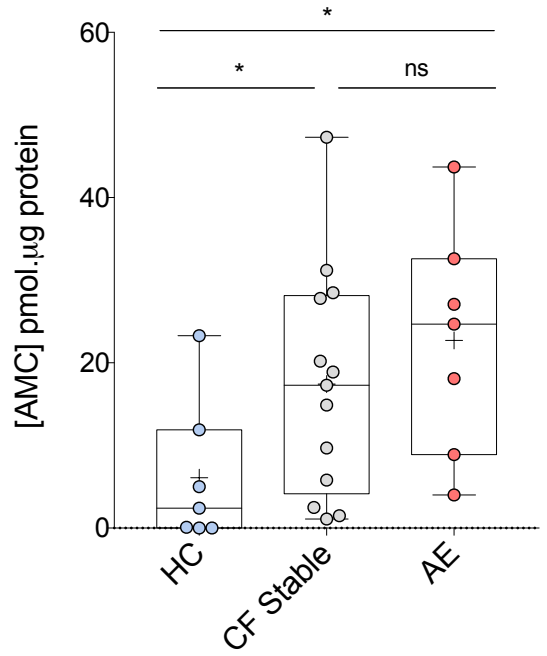

B

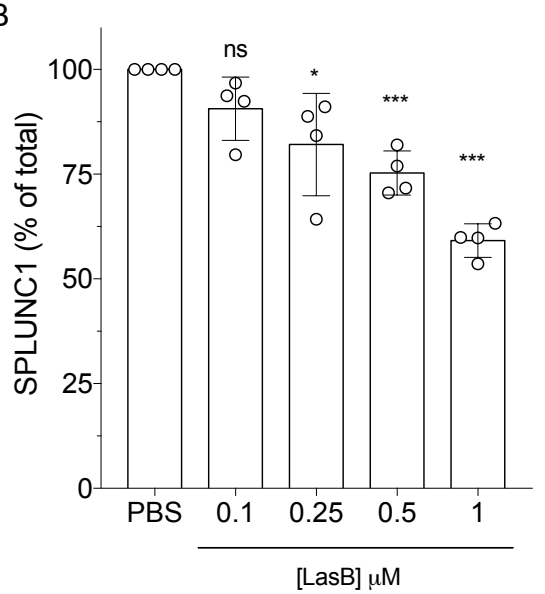

D

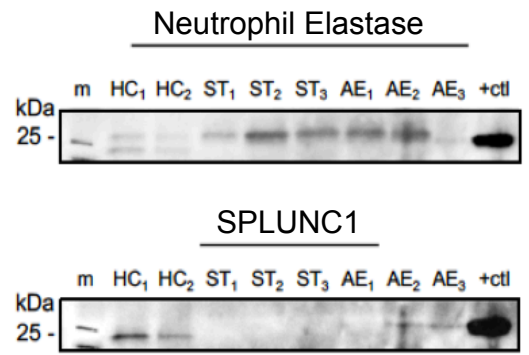

Figure 5. Elastase Concentration and Activity are Increased in CF. A) SPLUNC1 densitometry showing degradation by human neutrophil elastase (NE) relative to PBS control, at specified concentrations over 3 hours at $37^{\circ} \mathrm{C}$. B) SPLUNC1 densitometry showing degradation by Elastase B (LasB) from $P$. aeruginosa relative to PBS control at specified concentrations over 8 hours at $37^{\circ} \mathrm{C}$. C) NE densitometry in sputum from healthy controls (HC), Stable CF subjects (CF Stable), and AE subjects (AE) assessed by WB. D) Representative WB showing endogenous expression of SPLUNC1 (25 kD) and NE (25-30 kD) in HC and CF sputum samples from the same individual. Membranes were probed for NE prior to stripping and re-probing for SPLUNC1. E) NE Activity in CF sputum: AMC formation from florigenic NE substrate MAA-3133 following $6 \mathrm{~h}$ incubation with HC, $\mathrm{CF}$ stable, and $\mathrm{AE}$ sputum at $37^{\circ} \mathrm{C}$. For experiments in $A$ and $B: n=4-5,2$ individual experiments; Mann-Whitney Test; + = Mean; Bar inside box: Median; Whiskers: Minimum/Maximum; ${ }^{*} p<0.05 ;{ }^{* *}=p<0.01 ;{ }^{* * *}=p<0.005$; ns: not statistically significant; HC: Healthy Control; ST: Stable CF; AE: CF exacerbation; m: marker; +ctl: positive control; OD: optic density. 
medRxiv preprint doi: https://doi.org/10.1101/2020.05.15.20100669; this version posted May 19, 2020. The copyright holder for this preprint (which was not certified by peer review) is the author/funder, who has granted medRxiv a license to display the preprint in perpetuity.

It is made available under a CC-BY-NC-ND 4.0 International license .
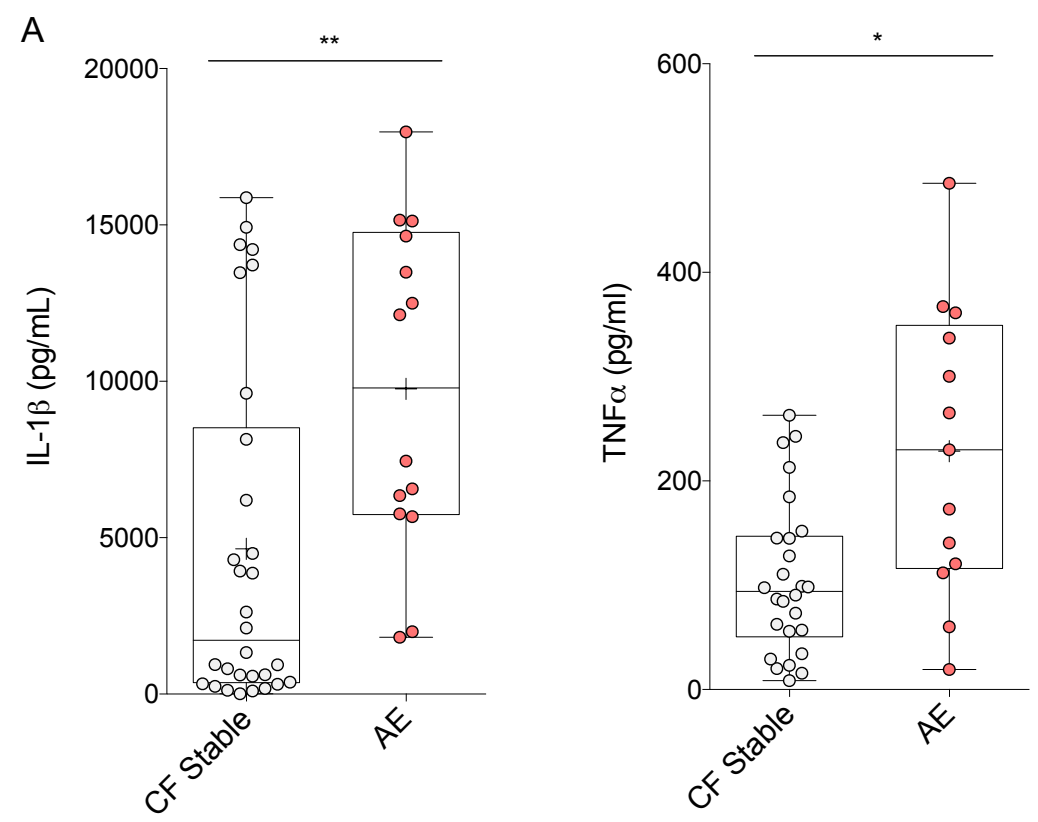

B Mouse epithelium

Human epithelium
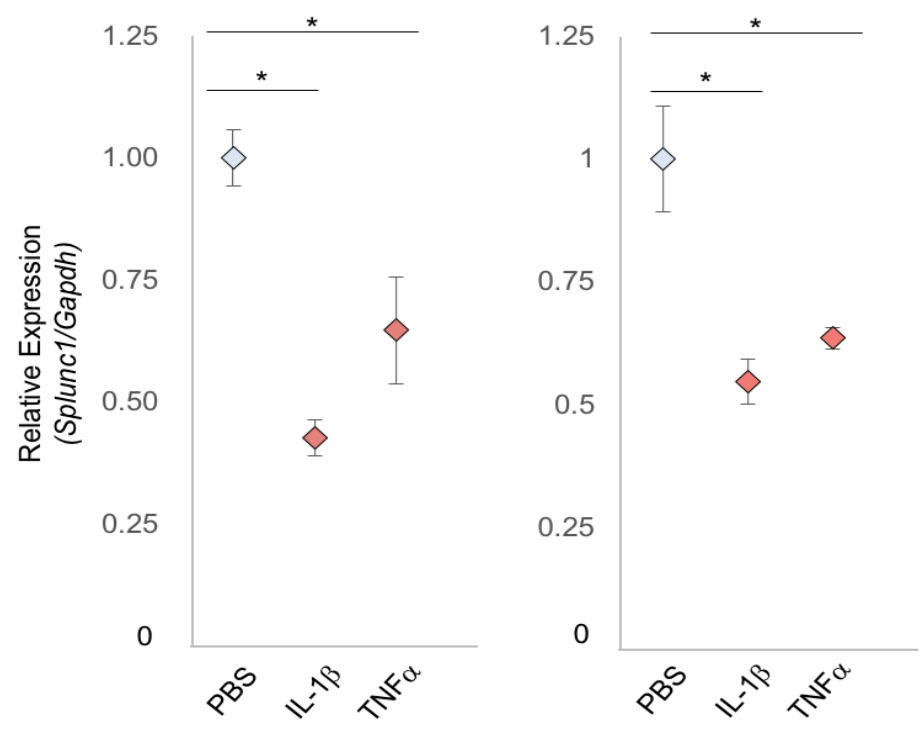

Figure 6. Cytokines IL-1 $\beta$ and TNF- $\alpha$ Increase During AE \& Downregulate SPLUNC1 Expression. A) Inflammatory cytokine levels in sputum from adult CF subjects without respiratory symptoms (CF Stable) and with acute CF Exacerbation (AE). Additional cytokines tested without significant difference: CXCL10, G-CSF, IFN 2 2, IFN $\gamma$, IFN $\lambda$, IL-6, IL-8, IL-13, MCP1, MIP1 $\alpha$. Mann-Whitney Test with Bonferroni correction. B) Relative SPLUNC1 mRNA expression in mouse tracheal epithelial cells (Mouse epithelium) grown at air-liquid interface and in the NClH292 human airway epithelial cell line (Human epithelium) treated with recombinant TNF $\alpha$ and IL-1 $1 \beta(10 \mathrm{ng} / \mathrm{mL})$ for 24 hours (2-way ANOVA); + = Mean; Bar inside box: Median; Whiskers: Minimum/Maximum; mRNA expression quantified by qPCR. Represents 2 experiments; * $=p<0.05 ;{ }^{* *}=p<0.01$. 
medRxiv preprint doi: https://doi.org/10.1101/2020.05.15.20100669; this version posted May 19, 2020. The copyright holder for this preprint (which was not certified by peer review) is the author/funder, who has granted medRxiv a license to display the preprint in perpetuity.

It is made available under a CC-BY-NC-ND 4.0 International license .

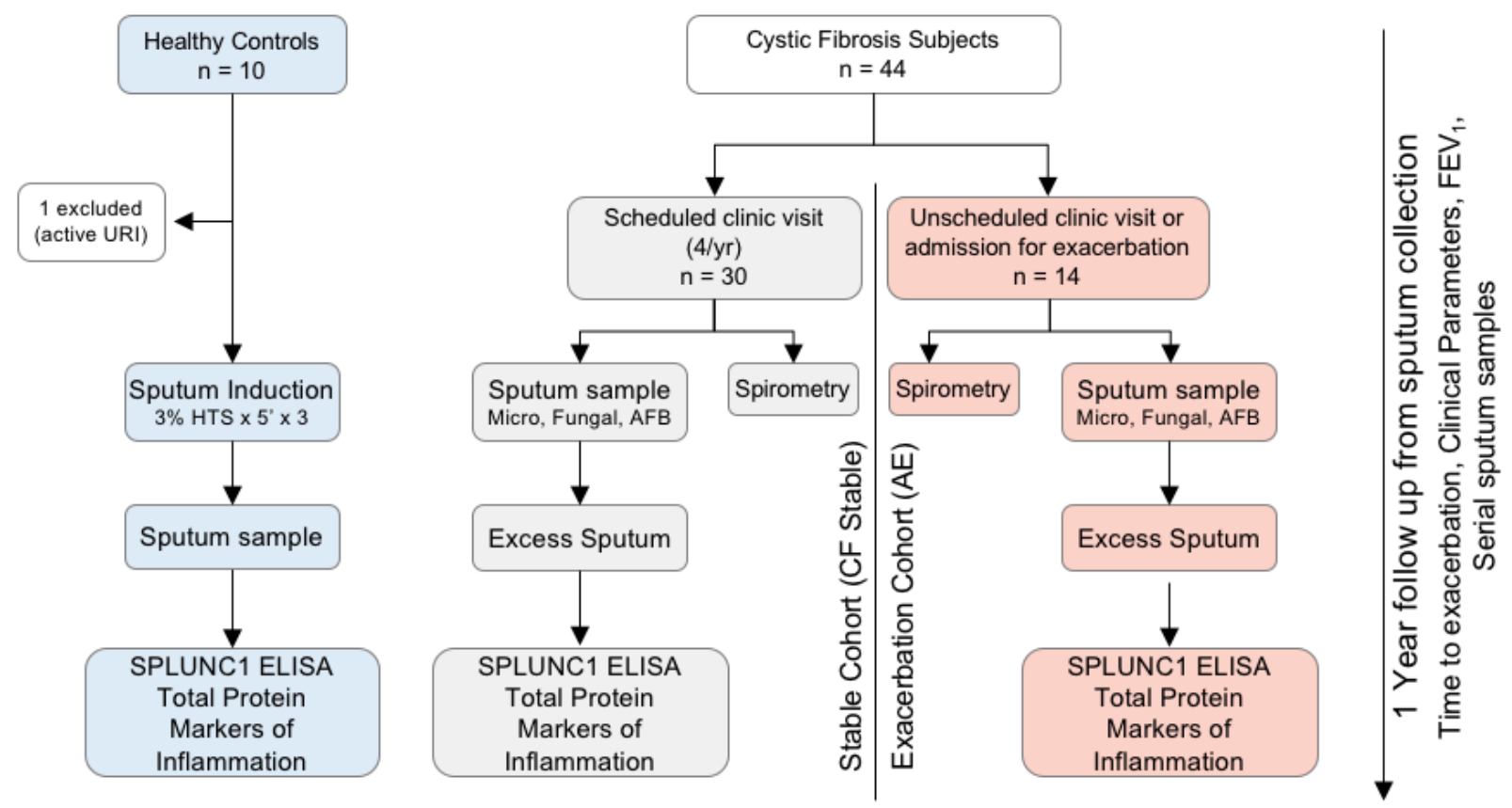

Supplemental Figure 1. Study design (Yale discovery cohort). Forty-four adult subjects with a confirmed diagnosis of CF were identified from the Yale Adult CF Program to participate in this study. These patients were recruited during their scheduled routine visits, unscheduled "sick" visits in which they reported new respiratory symptoms, and on their first day of admission to the hospital for treatment of a pulmonary exacerbation (AE). Our recruitment period extended from 2014-2016. We organized study subjects into two groups: 1) Stable CF subjects (CF Stable): Individuals without new respiratory symptoms, who presented to clinic for their scheduled quarterly follow up and, 2) Subjects having an $A E$ : Individuals with new respiratory symptoms, clinically diagnosed with $A E$ that were prescribed treatment for $A E$ during scheduled visit, unscheduled sick visit, or first day of hospital admission for AE. All CF subjects provided spontaneously expectorated sputum samples, sputum microbiology samples, and pulmonary function tests. Healthy controls underwent sputum induction. All subjects were followed for the development of $A E$ for one year counted form the date of sputum collection. 
medRxiv preprint doi: https://doi.org/10.1101/2020.05.15.20100669; this version posted May 19, 2020. The copyright holder for this preprint (which was not certified by peer review) is the author/funder, who has granted medRxiv a license to display the preprint in perpetuity. It is made available under a CC-BY-NC-ND 4.0 International license .

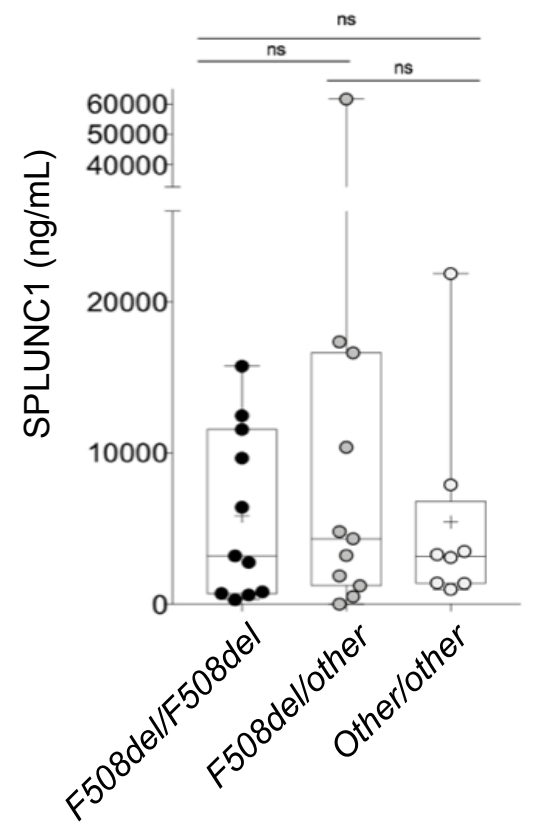

Supplemental Figure 2. SPLUNC1 does not change according to F508del genotype. A) SPLUNC1 levels (ELISA) in sputum samples from the Yale cohort of adult CF subjects without respiratory symptoms (CF Stable) organized by the presence of one, two, or no F508del mutations. Sputum Samples were obtained by voluntary expectoration during clinical assessment, $+=$ Mean; Bar inside box: Median; Whiskers: Minimum/Maximum. Mann-Whitney Test with Bonferroni correction; $\mathrm{ns}=$ not statistically significant. 
medRxiv preprint doi: https://doi.org/10.1101/2020.05.15.20100669; this version posted May 19, 2020. The copyright holder for this preprint (which was not certified by peer review) is the author/funder, who has granted medRxiv a license to display the preprint in perpetuity.

It is made available under a CC-BY-NC-ND 4.0 International license .

\section{SPLUNC1}

\section{G-CSF}

\section{$\mathrm{IL}-1 \beta$}

\begin{tabular}{|c|c|c|c|c|c|c|c|c|c|c|c|c|c|c|c|c|c|}
\hline Cutoff & Sensitivity\% & $95 \% \mathrm{Cl}$ & Specificity\% & $95 \% \mathrm{Cl}$ & Likelihood ratio & Cutoff & Sensitivity\% & $95 \% \mathrm{Cl}$ & Specificity\% & $95 \% \mathrm{Cl}$ & Likellhood ratio & Cutoff & Sensitivity\% & $95 \% \mathrm{Cl}$ & Specificily\% & $95 \% \mathrm{Cl}$ & Iikellihood ratio \\
\hline & 92.86 & & & & 3.095 & $<147.1$ & 68.75 & $41.34 \%$ to $88.98 \%$ & 46.67 & $28.34 \%$ to $65.67 \%$ & 1.289 & $>940.2$ & & & & & \\
\hline$<2165$ & 92.86 & $66.13 \%$ to $99.82 \%$ & 66.67 & $47.19 \%$ to $82.71 \%$ & 2.786 & $<153.7$ & 68.75 & $41.34 \%$ to $88.98 \%$ & 43.33 & $25.46 \%$ to $62.57 \%$ & 1.213 & $>1135$ & & $70.84 \% 1010$ & & 6 to $65.67 \%$ & 1.875 \\
\hline$*<2334$ & 100 & $76.84 \%$ to $100 \%$ & 66.67 & $47.19 \%$ to $82.71 \%$ & 3 & $*<171.6$ & 75 & $47.62 \%$ to $92.73 \%$ & 43.33 & $25.46 \%$ to $62.57 \%$ & 1.324 & $*>1574$ & 100 & $76.84 \%$ to 10 & 50 & $31.3 \%$ to $68.7 \%$ & \\
\hline$<2613$ & 100 & $76.84 \%$ to $100 \%$ & 63.33 & $43.86 \%$ to $80.07 \%$ & 2.727 & $\begin{array}{l}<191.2 \\
<198.5\end{array}$ & $\begin{array}{l}81.25 \\
87.5\end{array}$ & $\begin{array}{l}54.35 \% \text { to } 95.95 \% \% \\
61.56 \% \text { to } 98.54 \%\end{array}$ & $\begin{array}{l}43.33 \\
4433\end{array}$ & $\begin{array}{l}25.46 \% \text { to } 62.57 \% \\
25.64 \% \text { to } 62.5 \%\end{array}$ & $\begin{array}{l}1.434 \\
1.544\end{array}$ & $\begin{array}{l}>1907 \\
>2053\end{array}$ & $\begin{array}{l}92.86 \\
8871\end{array}$ & $66.13 \%$ to $99.82 \%$ & $\begin{array}{l}50 \\
50\end{array}$ & $31.3 \%$ to $68.7 \%$ & $\begin{array}{l}1.857 \\
1714\end{array}$ \\
\hline$<2935$ & 100 & $76.84 \%$ to $100 \%$ & & $40.6 \%$ to $77.34 \%$ & 2.5 & & & & & $25.46 \%$ to $62.57 \%$ & & & & $57.19 \%$ to $98.22 \%$ & & & 1.714 \\
\hline
\end{tabular}

ROC curve: ROC of Stables v Exa

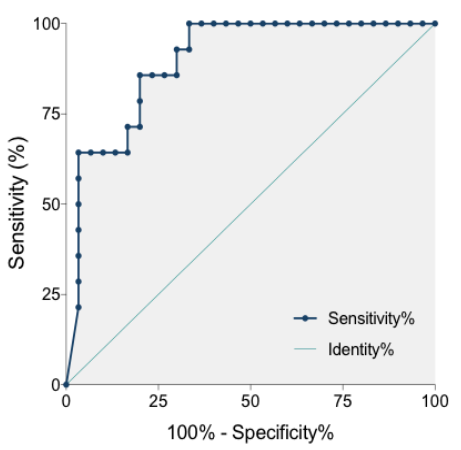

ROC curve: G-CSF Stables v. Exa

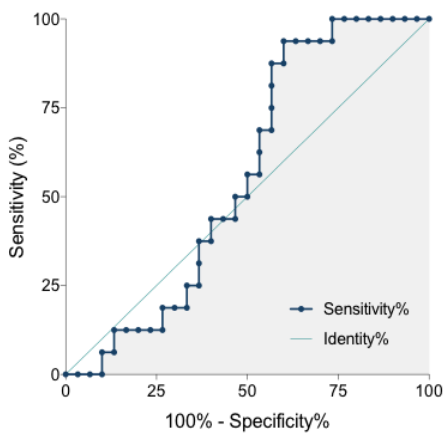

ROC curve: IL1b Stable v. Exa

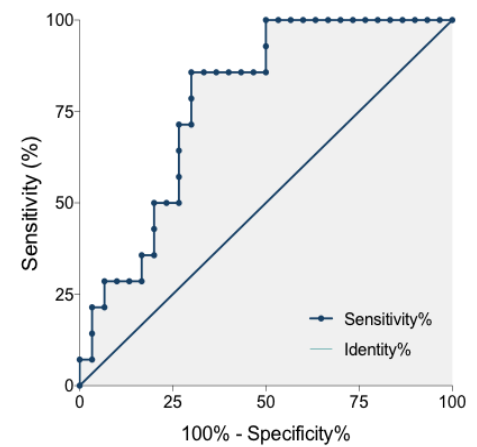

IL-6

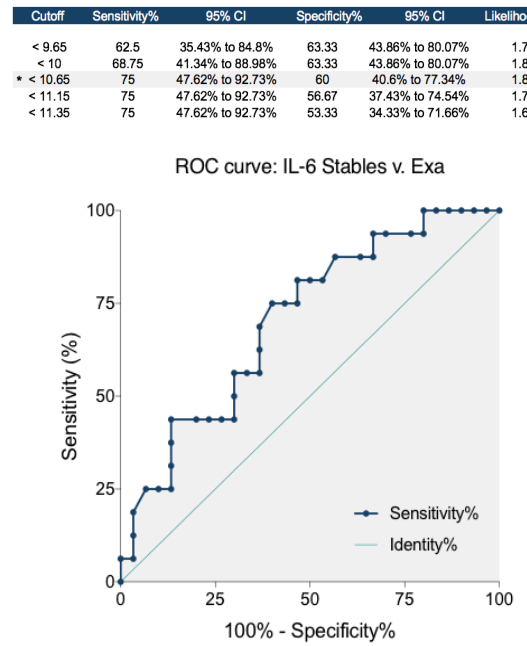

IL-8
$\mathrm{TNF} \alpha$

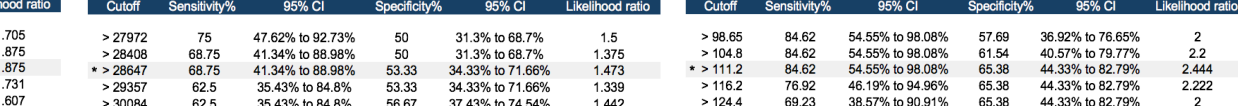

ROC curve: IL-8 Stables v. Exa

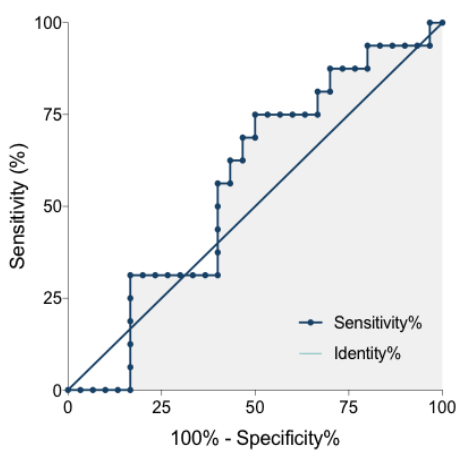

ROC curve: TNFa Stable v. Exa

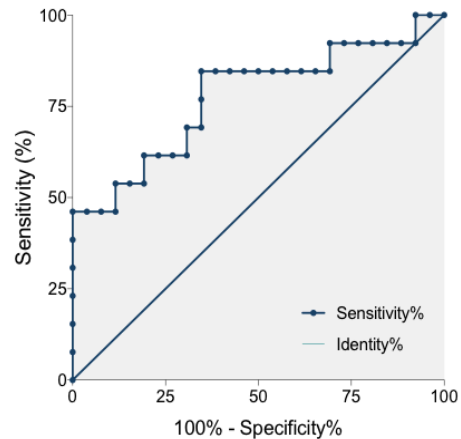

Supplemental Figure 3. Receiver Operator Curve Development for defining SPLUNC1-, IL-1 $\beta$, TNF $\alpha$, GCSF, IL-6, and IL-8- High and Low categories. Cutoff values $\left(^{*}\right)$ were selected to provide maximum sensitivity with the highest specificity possible (highlighted in gray). 
medRxiv preprint doi: https://doi.org/10.1101/2020.05.15.20100669; this version posted May 19, 2020. The copyright holder for this preprint (which was not certified by peer review) is the author/funder, who has granted medRxiv a license to display the preprint in perpetuity. It is made available under a CC-BY-NC-ND 4.0 International license .

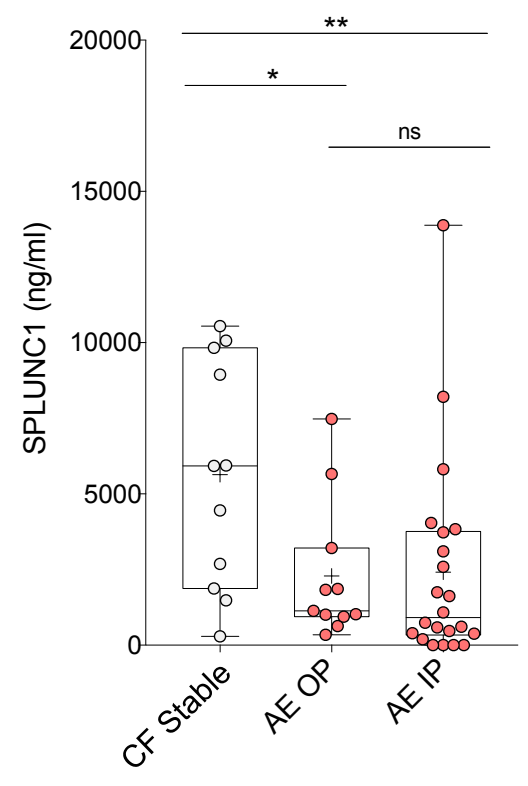

Supplemental Figure 4. SPLUNC1 is Decreased During CF Exacerbations Requiring Outpatient or Inpatient Antibiotic Treatment. SPLUNC1 levels in sputum samples from a clinical cohort including adult and pediatric CF subjects (University of Minnesota). Samples were obtained by voluntary expectoration during clinical assessment, SPLUNC1 quantified by ELISA. CF Stable: No symptoms of AE, no antibiotic treatment. AE Outpatient (AE OP): Clinical symptoms consistent with exacerbation, treated with oral antibiotics at the time of sputum collection. $A E$ Inpatient (AE IP): Admitted for inpatient antibiotic course, sample collected during first day of treatment. + = Mean; Bar inside box: Median; Whiskers: Minimum/Maximum; Mann-Whitney test; ${ }^{*}=p<0.05,{ }^{* *}=p<0.01, n s=$ not statistically significant. 
medRxiv preprint doi: https://doi.org/10.1101/2020.05.15.20100669; this version posted May 19, 2020. The copyright holder for this preprint (which was not certified by peer review) is the author/funder, who has granted medRxiv a license to display the preprint in perpetuity.

It is made available under a CC-BY-NC-ND 4.0 International license .

A

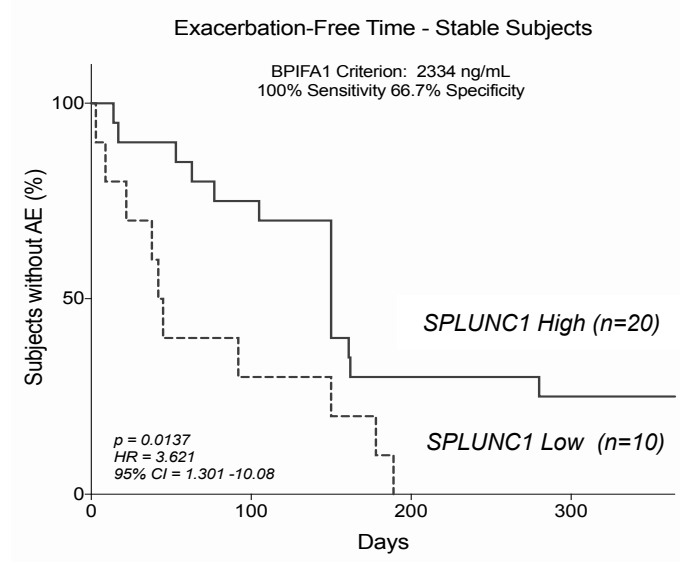

B

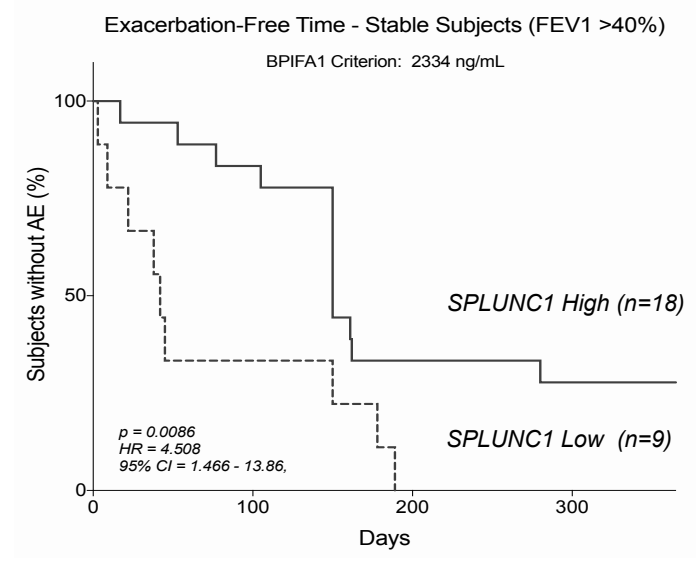

Supplemental Figure 5. SPLUNC1 Predicts AE-Free Time (unadjusted survival model). A) Stable CF subjects were separated into SPLUNC1-high and SPLUNC1-Low groups according to a SPLUNC1 threshold of $2334 \mathrm{ng} / \mathrm{mL}$. Time to AE in was measured over 365 days from the date of sputum collection in all subjects. B) Stable subjects with an $\mathrm{FEV}_{1}>40 \%$ of predicted were separated into SPLUNC1-high and SPLUNC1-low cohorts as above. Time to exacerbation was measured for up to one year from the date of sputum collection. Mantel-Haenszel estimator was used to calculate exacerbation-free interval in each group. Values are not adjusted for clinical variables. Adjusted values from a Cox proportional hazards model are presented in Figure 6. AE: CF exacerbation, HR: Hazard ratio, Cl: Confidence interval. 
medRxiv preprint doi: https://doi.org/10.1101/2020.05.15.20100669; this version posted May 19, 2020. The copyright holder for this preprint (which was not certified by peer review) is the author/funder, who has granted medRxiv a license to display the preprint in perpetuity.

A) It is made available under a CC-BY-NC-ND 4.0 International license .

B)

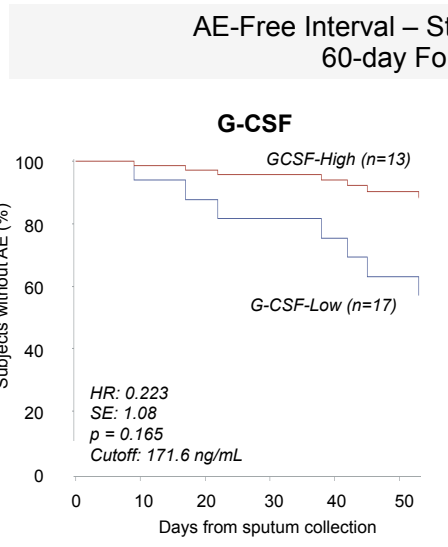

IL-6

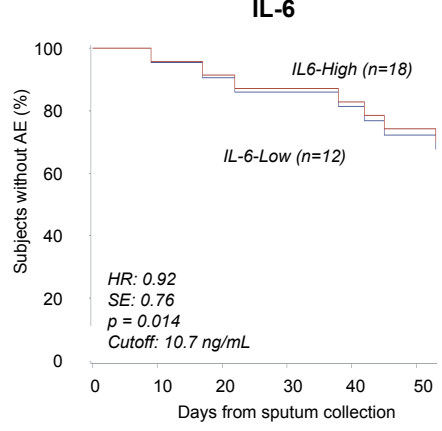

TNF $\alpha$

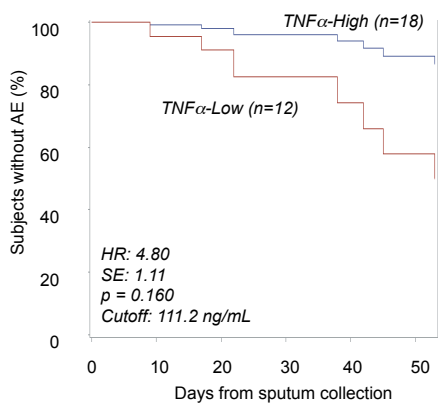

AE-Free Interval - Stable CF Subjects 365-day Follow-up

$L-1 \beta$

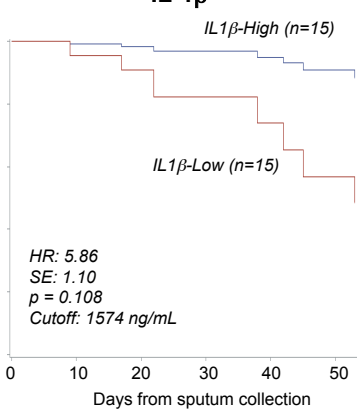

G-CSF

IL-1 $\beta$
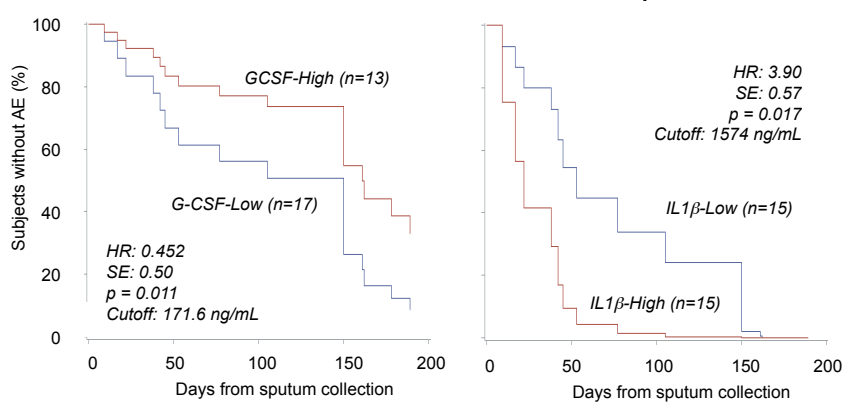

IL-6

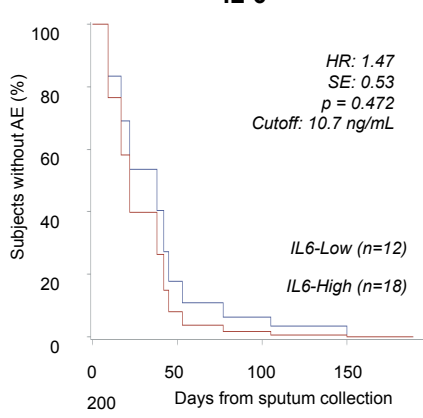

IL-8
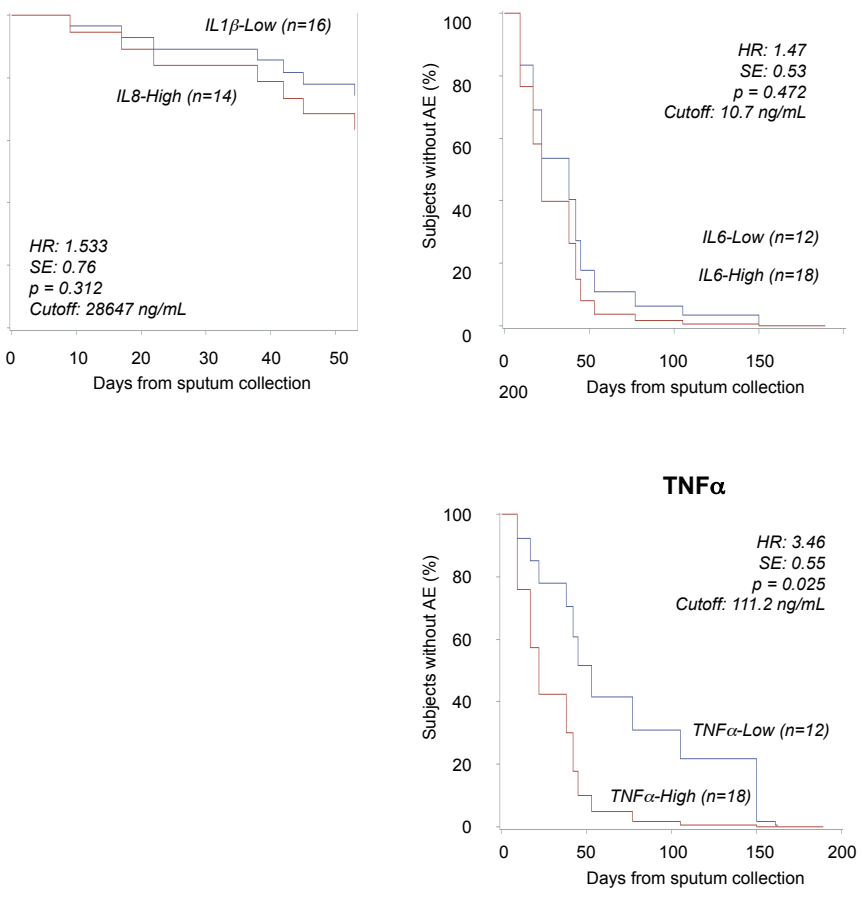

Supplemental Figure 6. Sputum Cytokines Do Not Predict Short Term AE-Free Time. (A) AE-Free time in Stable CF subjects separated into IL-1 $\beta-$, TNF $\alpha$-, G-CSF-, IL-6-, and IL-8-High and -Low groups over a 60-day follow up period. Marker-high and -low groups were defined according to sputum concentration thresholds obtained from ROCs separating CF Stable and AE levels (Supplemental Figure 3). AE-Free time was defined as the number of days from sputum collection in Stable subjects until the date of their next AE. (B) AE-Free time in Stable CF subjects separated into IL-1 $\beta-$-, TNF $\alpha$-, G-CSF-, IL-6-, and IL-8-High and -Low groups over a 365-day follow up period. Cox Proportional Hazards model used to calculate AE-free intervals and adjust for age, sex, BMI, FEV ${ }_{1}$, number of $F 508 d e /$ mutations, presence of CF-related diabetes or pancreatic insufficiency, use of CFTR correctors/modulators, and microbiology for $P$. aeruginosa, A. xylosoxidans, $H$. parainfluenzae, Methicillin-sensitive $S$. aureus, and Methicillin-resistant $S$. aureus. HR: Hazard ration; SE: Standard error. 
medRxiv preprint doi: https://doi.org/10.1101/2020.05.15.20100669; this version posted May 19, 2020. The copyright holder for this preprint (which was not certified by peer review) is the author/funder, who has granted medRxiv a license to display the preprint in perpetuity.

It is made available under a CC-BY-NC-ND 4.0 International license .

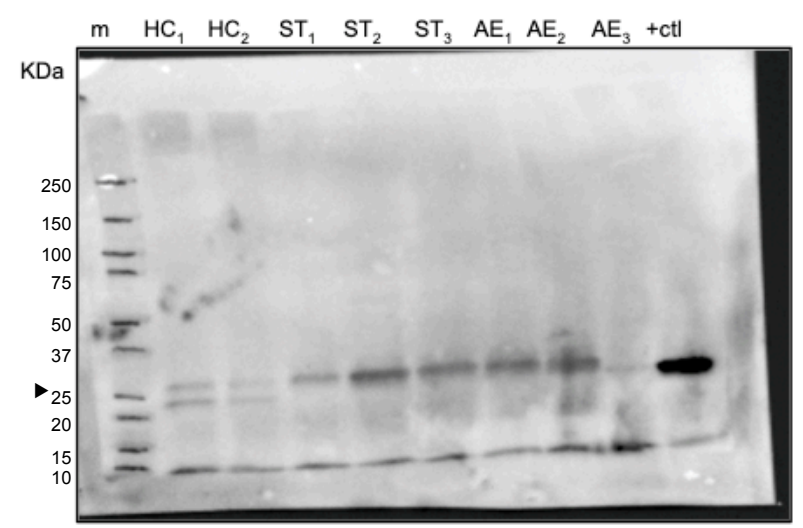

B SPLUNC1

$\begin{array}{lllllllllll}m & \mathrm{HC}_{1} & \mathrm{HC}_{2} & \mathrm{ST}_{1} & \mathrm{ST}_{2} & \mathrm{ST}_{3} & \mathrm{AE}_{1} & \mathrm{AE}_{2} & \mathrm{AE}_{3} & +\mathrm{ctl}\end{array}$

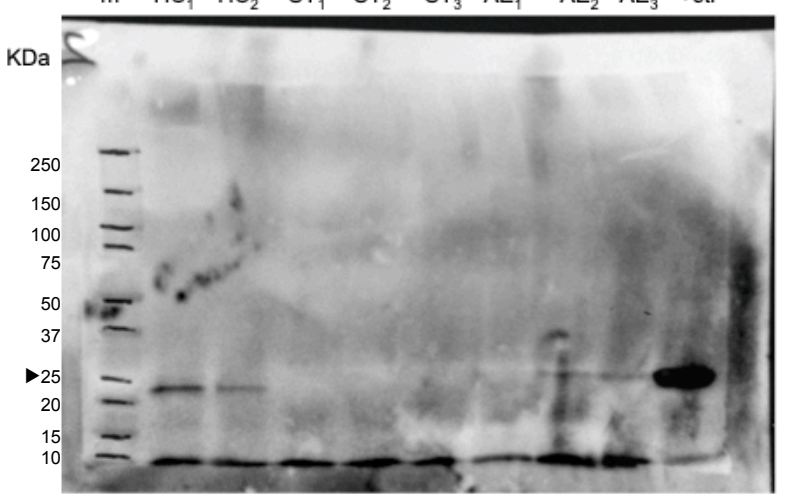

Supplemental Figure 7. Full unedited WB for figure 5D. Membranes were initially probed for NE prior to stripping and re-probing for SPLUNC1. A) NE antibody: Mouse monoclonal anti-hELA2 raised against residues M1-N252 (1:3000, R\&D systems). B) SPLUNC1 antibody: goat polyclonal hPLUNC1 antibody raised against residues Q20 V256 of hPLUNC1 (1:3000, R\&D systems), a secondary anti-goat HRP. HC: Healthy Control; ST: Stable CF; AE: CF exacerbation; m: marker; +ctl: positive control. 